\title{
HYDROGEOLOGY AND GROUND-WATER RESOURCES OF PINGELAP ISLAND, PINGELAP ATOLL, STATE OF POHNPEI, FEDERATED STATES OF MICRONESIA
}

\section{U.S. GEOLOGICAL SURVEY}

Water-Resources Investigations Report 92-4005

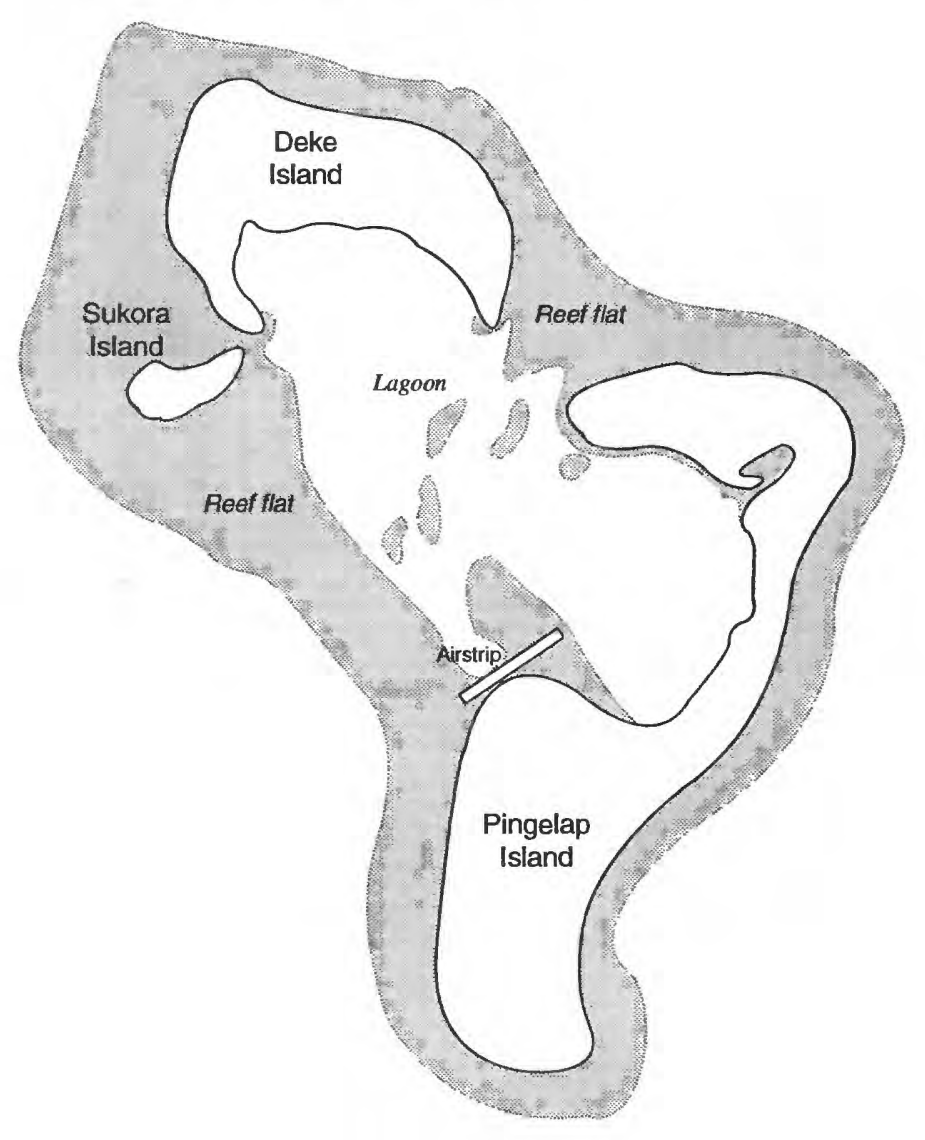

Prepared in cooperation with the

STATE OF POHNPEI, DEPARTMENT OF CONSERVATION AND RESOURCE SURVEILLANCE

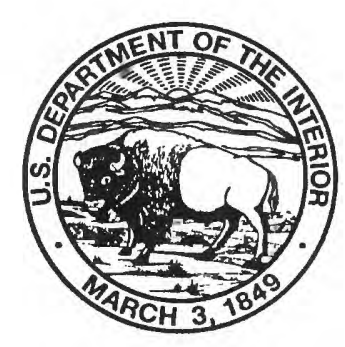




\title{
U.S. DEPARTMENT OF THE INTERIOR BRUCE BABBITT, Secretary
}

\author{
U.S. GEOLOGICAL SURVEY \\ Gordon P. Eaton, Director
}

Any use of trade, product, or firm names in this publication

is for descriptive purposes only and does not imply

endorsement by the U.S. Government

For sale by the

U.S. Geological Survey

Branch of Information Services

Box 25286

Denver, CO 80225-0286

For additional information write to:

District Chief

U.S. Geological Survey

677 Ala Moana Blvd., Suite 415

Honolulu, HI 96813 


\section{CONTENTS}

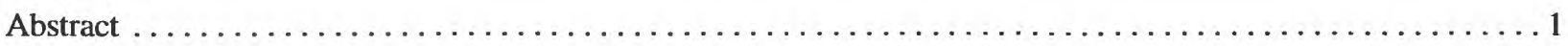

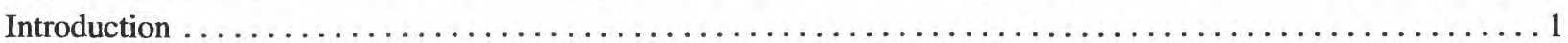

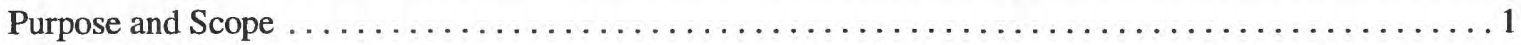

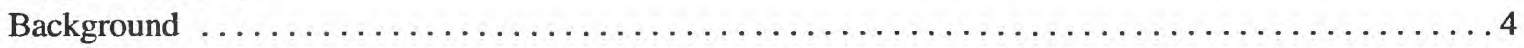

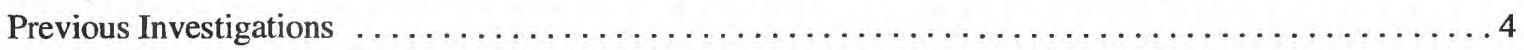

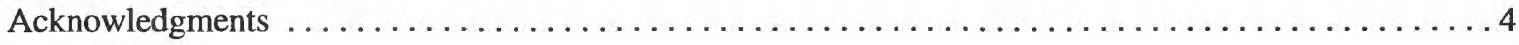

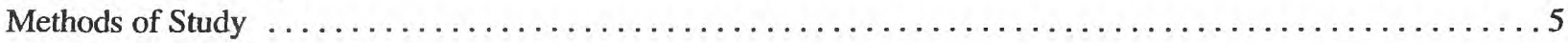

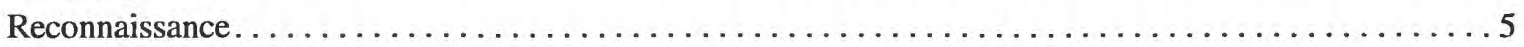

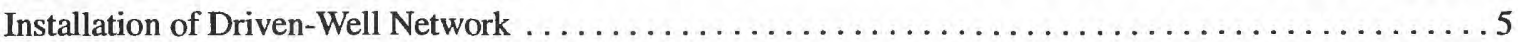

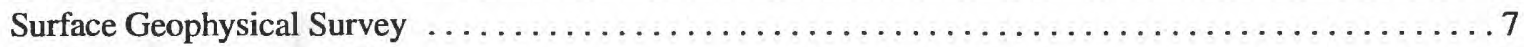

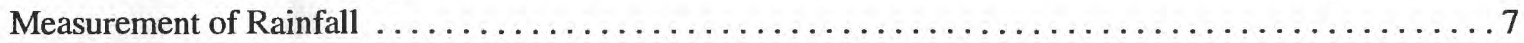

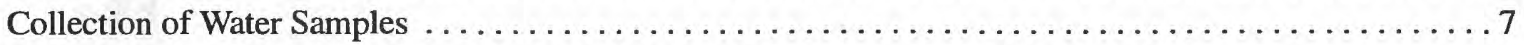

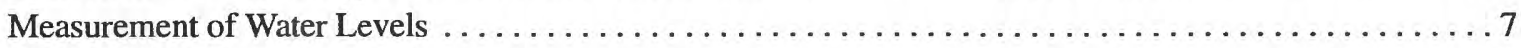

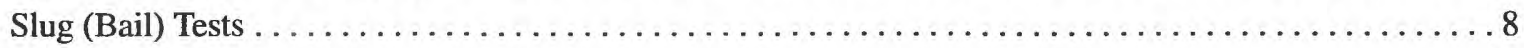

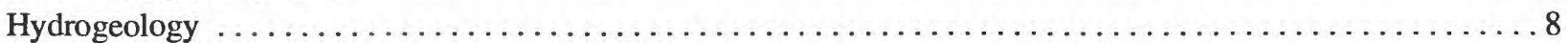

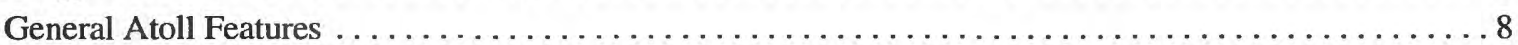

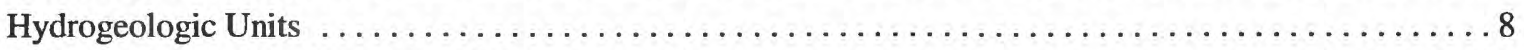

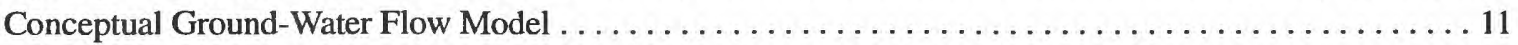

Hydraulic Characteristics . . . . . . . . . . . . . . . . . . . . . . . . . . . 11

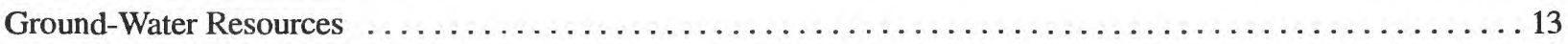

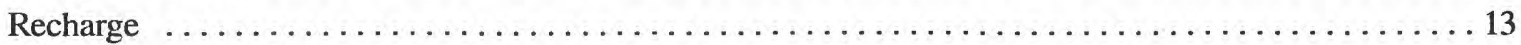

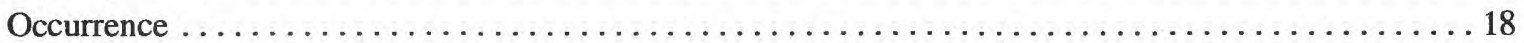

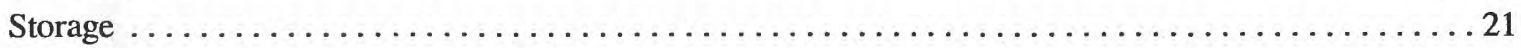

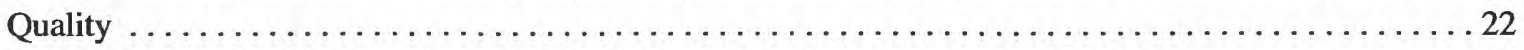

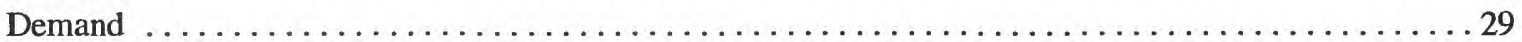

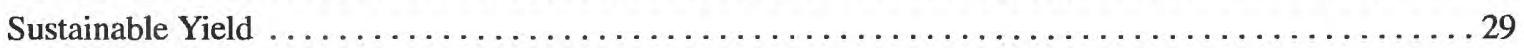

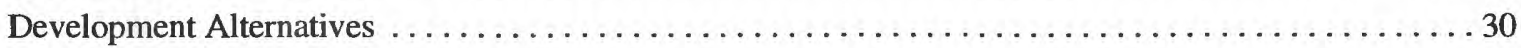

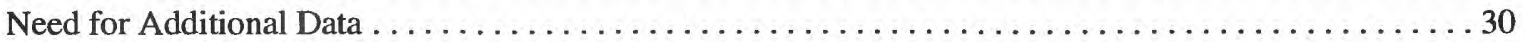

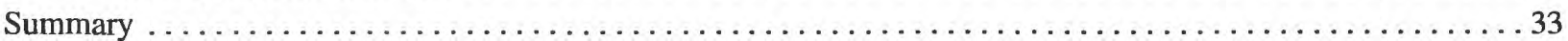

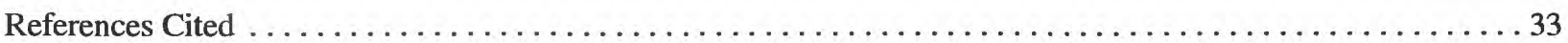

\section{FIGURES}

1-3. Maps showing:

1. Location of Pingelap Atoll, State of Pohnpei, Federated States of Micronesia . . . . . . . . . . 2

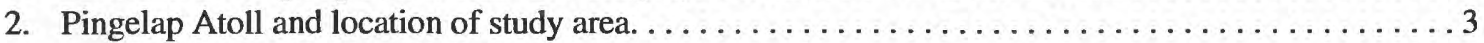

3. Location of dug wells, driven wells, and line of section, Pingelap Island, Pingelap Atoll ....... 6

4-6. Drawings showing:

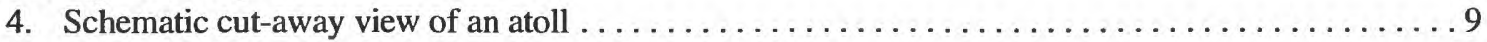

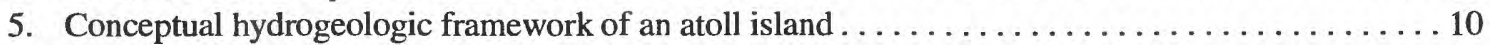

6. Schematic section of freshwater lens with transition zone, and graph showing relation of salinity and depth.

7-9. Graphs showing:

7. Variation in tidal-efficiency with depth for selected driven-well sites, Pingelap Island, Pingelap Atoll 
8. Variation in hydraulic conductivity with depth for selected driven-well sites, Pingelap Island, Pingelap Atoll . . . . . . . . . . . . . . . . . . . . . . . . . . . . 15

9. Mean monthly rainfall, based on intermittent monthly totals from November 1985 through April 1990, Pingelap Island, Pingelap Atoll . . . . . . . . . . . . . . . . . . . . 18

10-11. Map showing:

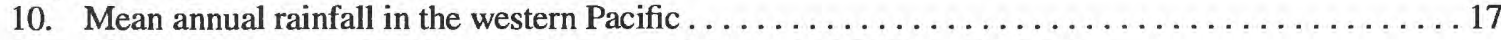

11. Chloride concentration of ground water at the water table, Pingelap Island,

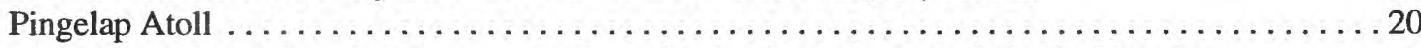

12. Graph showing variation in chloride concentration with depth at driven-well site $D$, Pingelap

Island, Pingelap Atoll . . . . . . . . . . . . . . . . . . . . . . . . . 21

13-14. Diagrams showing:

13. Hydrologic section through the Pingelap freshwater lens, September 1988, Pingelap Island, Pingelap Atoll. . . . . . . . . . . . . . . . . . . . . . . 22

14. Hydrologic and geophysical sections through the Pingelap freshwater lens, August 1989, Pingelap Island, Pingelap Atoll . . . . . . . . . . . . . . . . . . . . . . . 23

15-16. Maps showing:

15. Estimated depth to the electromagnetic-interpreted interface and thickness of potable freshwater, Pingelap Island, Pingelap Atoll. . . . . . . . . . . . . . . . . . . . . 24

16. Estimated depth to the base of the freshwater nucleus, Pingelap Island, Pingelap Atoll . . . . . . 25

17-18. Graphs showing:

17. Variation in relative salinity with depth, Pingelap Island, Pingelap Atoll

a. Driven-well site B . . . . . . . . . . . . . . . . . . . . . . . . . . 26

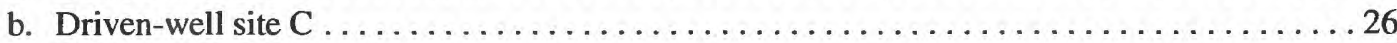

c. Driven-well site D . . . . . . . . . . . . . . . . . . . . . . . . . . . 26

d. Driven-well site E . . . . . . . . . . . . . . . . . . . . . . . . . . 27

e. Driven-well site I. . . . . . . . . . . . . . . . . . . . . . . . . 27

18. Monthly rainfall totals for August 1988 through May 1990, Pingelap Island, Pingelap Atoll . . . . 28

19-20. Diagrams showing schematic of:

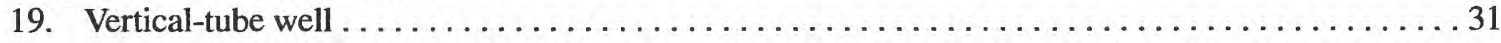

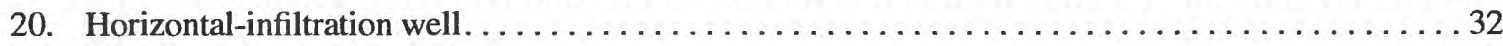

\section{TABLES}

1. Driven-well construction information, Pingelap Island, Pingelap Atoll $\ldots \ldots \ldots \ldots \ldots \ldots \ldots \ldots \ldots$

2. Temperature, specific conductance, and chloride-concentration data from dug wells, Pingelap

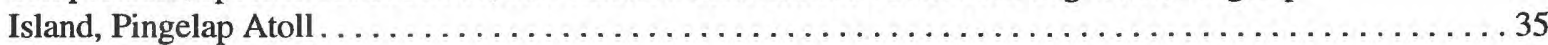

3. Temperature, specific conductance, and chloride-concentration data from driven wells, Pingelap Island, Pingelap Atoll . . . . . . . . . . . . . . . . . . . . . . . . . 37

4. Water-quality data from selected dug and driven wells collected March 1990, Pingelap Island,

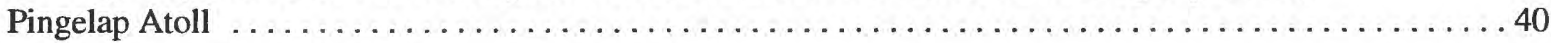

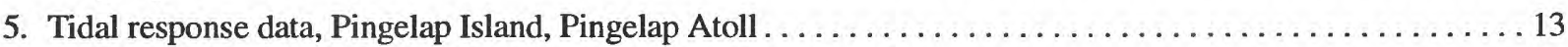

6. Monthly and annual rainfall data, Pingelap Island, Pingelap Atoll $\ldots \ldots \ldots \ldots \ldots \ldots \ldots \ldots \ldots \ldots \ldots \ldots \ldots \ldots \ldots$

7. Relation between reduction in recharge and thickness of freshwater lens, Pingelap Island, Pingelap Atoll. . . . . . . . . . . . . . . . . . . . . . . . . . . . . . . . . . 29 


\begin{tabular}{rcl}
\hline Multiply & By & To obtain \\
acre & 4,047 & square meter \\
foot (ft) & 0.3048 & meter \\
foot per day (ft/d) & 0.3048 & meter per day \\
gallon (gal) & 3.785 & liter \\
gallon per minute (gal/min) & 0.06308 & cubic decimeter per minute \\
gallon per day (gal/d) & 0.003785 & cubic meter per day \\
inch (in.) & 25.4 & millimeter \\
inch per year (in/yr) & 2.54 & centimeter per year \\
mile (mi) & 1.609 & kilometer \\
million gallons (Mgal) & 3,785 & cubic meter \\
million gallons per day (Mgal/d) & 0.04381 & cubic meter per second \\
million gallons per day per square mile [(Mgal/d)/mi $\left.{ }^{2}\right]$ & 1,460 & cubic meter per day per square kilometer \\
ounce (oz) & 28.35 & gram \\
square foot (ft) & 0.09294 & square meter \\
square mile (mi) & 2.590 & square kilometer
\end{tabular}

Abbreviations used: $\mathrm{g} / \mathrm{cm}^{3}$, grams per cubic centimeter; g/d, grams per day; $\mu \mathrm{mho} / \mathrm{m}$, micromhos per meter; meq/L, milliequivalents per liter; $\mathrm{mg} / \mathrm{L}$, milligrams per liter; $\mathrm{mS} / \mathrm{m}$, millisiemens per meter.

Specific conductance is given in microsiemens per centimeter $(\mu \mathrm{S} / \mathrm{cm})$ at $25^{\circ} \mathrm{Celsius,}$, which is numerically equal to micromhos per centimeter $(\mu \mathrm{mho} / \mathrm{cm})$.

Temperature is given in degrees Celsius $\left({ }^{\circ} \mathrm{C}\right)$, which can be converted to degrees Fahrenheit $\left({ }^{\circ} \mathrm{F}\right)$ by using the equation:

$$
1.8 \times{ }^{\circ} \mathrm{C}+32={ }^{\circ} \mathrm{F}
$$




\title{
Hydrogeology and Ground-Water Resources of Pingelap Island, Pingelap Atoll, State of Pohnpei, Federated States of Micronesia
}

\author{
By Stephen S. Anthony
}

\section{Abstract}

The lens of fresh ground water on Pingelap Island, Pingelap Atoll contains about 384 million gallons of potable water. Recharge to the freshwater lens is estimated to be 230,000 gallons per day on the basis of an average annual rainfall of 160 inches. The long-term average sustainable yield is estimated to be about 69,000 gallons per day. The estimated demand for water is about 50,000 gallons per day. Shallow-vertical-tube wells or horizontalinfiltration wells could be used to develop the freshwater lens. The effect of development on the lens can be determined by monitoring the chloride concentration of water from a network of shallowwater-table wells and deep driven wells.

The ground-water resource on Pingelap can be used in conjunction with individual rainwatercatchment systems: rainwater can be used for drinking and cooking, and ground water can be used for sanitary uses. When rainwater-catchment systems fail during extended dry periods, ground water would be available to meet the total demand.

\section{INTRODUCTION}

The demand for water on Pingelap Atoll in the State of Pohnpei, Federated States of Micronesia (fig. 1) is expected to increase as a result of a desire to construct sanitary facilities such as showers, flush toilets, and laundry facilities. Water supplies on Pingelap are obtained from individual and community rainwatercatchment systems and from shallow dug wells that yield fresh to brackish ground water. During extended dry periods the demand for potable water commonly exceeds the supply.
The water-supply problem on Pingelap was accentuated during a drought in 1983. Although rainfall was not recorded on Pingelap during 1983, rainfall on the island of Pohnpei, $188 \mathrm{mi}$ to the northwest, was only 13 percent of normal for the period January through May 1983 (van der Brug, 1986). The subnormal rainfall created a severe shortage because most of the potable water on Pingelap comes from rainwater-catchment systems. In addition to strict rationing of the water supply, it was necessary to use shallow dug wells as a source of drinking water. One way to alleviate the chronic water-supply shortage would be to further develop ground-water resources for non-potable use so that rainwater can be saved for drinking and cooking. To address the watersupply concerns of Pingelap Atoll, the U.S. Geological Survey (USGS), in cooperation with the State of Pohnpei, Department of Conservation and Resource Surveillance, made a hydrogeologic study to describe the ground-water resources of the atoll. Similar studies were made for Mwoakilloa and Sapwuahfik Atolls (Anthony, 1996a,b).

\section{Purpose and Scope}

The purpose of this report is to describe the hydrogeology and ground-water resources of Pingelap Atoll. Pingelap, the only inhabited island at Pingelap Atoll, is the focus of the report (fig. 2).

This report describes the occurrence, quantity, and quality of fresh ground water beneath Pingelap Island. Information from an inventory of existing shallow dug wells provides a basis for a preliminary assessment of the nature of the resource. The thickness and areal extent of this fresh ground-water body were determined on the basis of a surface geophysical survey and chloride-concentration data collected from a network of driven wells installed during the study. The quality of ground water was determined on the basis of chemical 

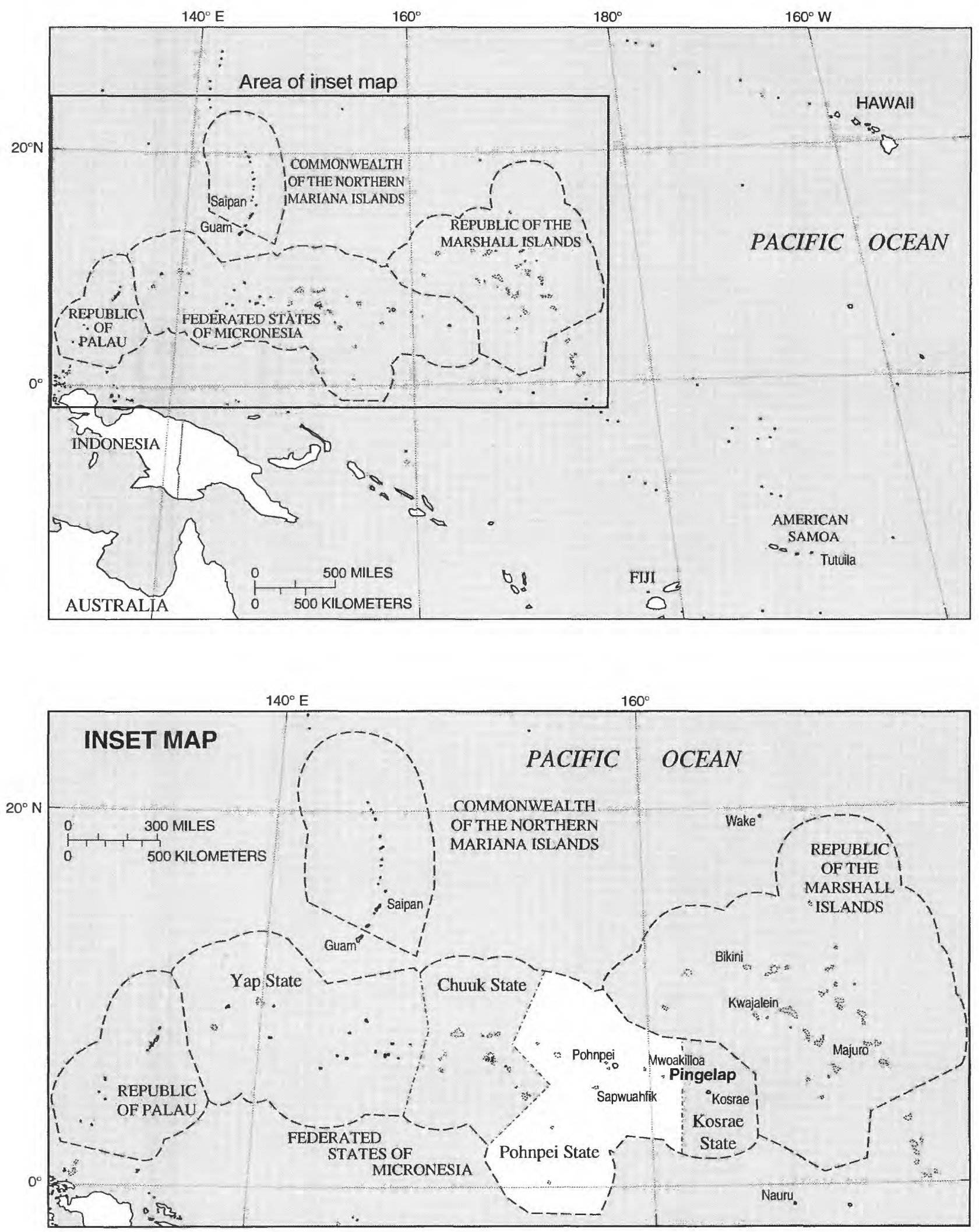

Figure 1. Location of Pingelap Atoll, State of Pohnpei, Federated States of Micronesia. 


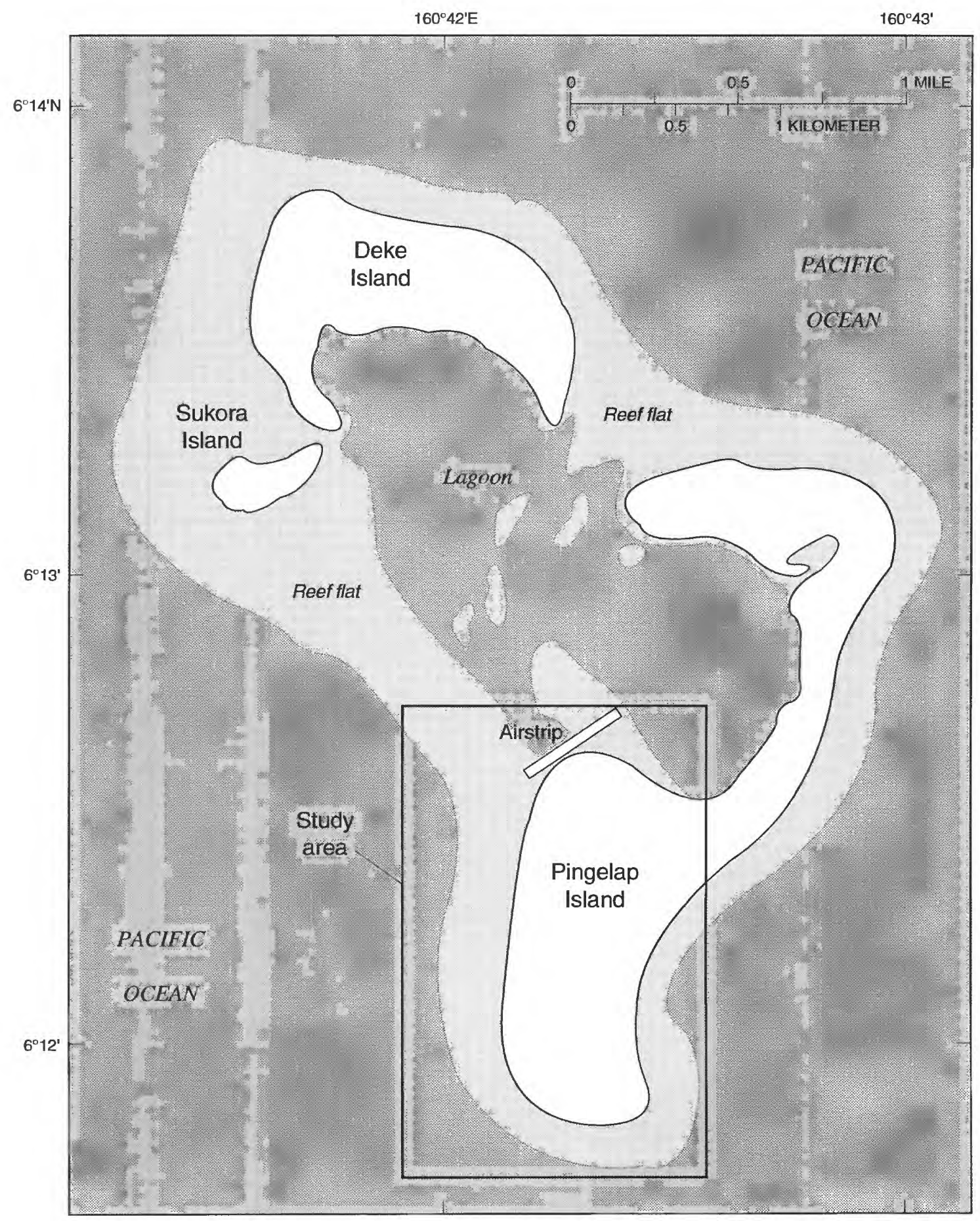

Figure 2. Pingelap Atoll and location of study area. 
analyses of water samples collected from selected dug wells and driven wells. A conceptual model of the hydrogeology of Pingelap Island was developed from near-surface observations combined with published descriptions of the hydrogeology of other atoll islands. Ground-water occurrence is related to assumed variations in lithology and is clarified by observations of ground-water quality and tidal fluctuations. This report discusses changes in storage of freshwater during a 19month period (September 1988 through March 1990). Estimates of water demand and sustainable yield of the ground-water resource, development alternatives, and the need for additional data are discussed.

\section{Background}

Geography.--Pingelap Atoll is located at latitude $6^{\circ} 13^{\prime} \mathrm{N}$. and longitude $160^{\circ} 42^{\prime} \mathrm{E}$ (fig. 1). Geographically, Pingelap is part of the Caroline Islands archipelago of the western Pacific. The atoll is about $188 \mathrm{mi}$ southeast of Pohnpei and about 3,000 mi southwest of Hawaii. Pingelap is small, compared with other atolls, $2.5 \mathrm{mi}$ long from north to south, and about $2 \mathrm{mi}$ wide from east to west (fig. 2). Three islets, composed mostly of coralline sand, are scattered along a reef that encloses a lagoon having a surface area of $0.46 \mathrm{mi}^{2}$. The total land area of the atoll islets is $0.68 \mathrm{mi}^{2}$, and the maximum altitude is less than $25 \mathrm{ft}$ above sea level. Pingelap Island, located on the southern and leeward side of the atoll, is the only inhabited island at Pingelap Atoll and has a total land area of $0.45 \mathrm{mi}^{2}$. A population of about 870 people live in a village that is strung along the western shore of the island (State of Pohnpei, Office of Budget, Planning and Statistics, 1990).

Climate.--Pingelap, located near the equator, has the characteristic climatic features of high temperature, cloudiness, and high humidity. Precipitation is heavy, averaging about $160 \mathrm{in} / \mathrm{yr}$; however, droughts are common. Wind direction and strength rather than rainfall or temperature distinguish one season from the other.

Northeasterly trade winds dominate from about November to June. By about April the trades begin to diminish in strength, and by July they have given way to the lighter more variable winds of the Intertropical Convergence Zone (ITCZ). Between July and November the climate of the island is frequently under the influence of the ITCZ which has moved northward. This is the season when moist southerly winds and tropical disturbances are most frequent.
Although Pingelap is located within the spawning grounds of typhoons, the major typhoon tracks of the western Pacific lie well to the north and west. However, typhoons have caused extensive damage to crops and homes on the island on several occasions. The most recent typhoon, Lola, struck Pingelap in 1986. Typhoons of recent years, however, have not been as severe as the one in 1905 that required the evacuation of many Pingelapese to Pohnpei.

Political history--Pingelap Atoll is politically part of the State of Pohnpei, Federated States of Micronesia. The modern history of the Pingelapese people stems from their contact with whaling ships and traders. The first recorded contact was in 1793 by Captain Musgrave aboard the vessel Sugar Cane (Ashby, 1987). Between 1886 and 1986 several foreign flags were flown in the islands; the Spanish flag from 1886 to 1899 , the German flag from 1899 to 1914 , the Japanese flag from 1914 to 1945, and the American flag from 1945 to 1986. While under a Trusteeship Agreement between the United States and the United Nations Security Council, Pohnpei (Ponape) joined in a union with Yap, Chuuk (Truk), and Kosrae (Kusaie) to form the Federated States of Micronesia in 1979. A Compact of Free Association between the Federated States of Micronesia and the United States was approved by the United Nations Trusteeship Council in 1986.

\section{Previous Investigations}

A detailed hydrogeologic study of Deke, an uninhabited island at the northern end of Pingelap Atoll, was made in 1984 by Ayers and Vacher (1986). Integrated studies of surface geology and physiography, water levels, surface geophysics (seismic refraction and resistivity), and subsurface core samples were used to describe the hydrogeologic system at Deke. Ayers and Vacher (1986) found that the occurrence and flow of ground water in the island is governed by the lagoonward edge of a well-indurated reef-flat plate that extends beneath the northern part of the island. The reef-flat plate was found to be impermeable and to occur at sea level.

\section{Acknowledgments}

Interest in and support for the project by the former Governor of Pohnpei, the Honorable Resio Moses, is gratefully acknowledged. Mr. Antonio Actouka, Chief of the Energy Division, Department of Conservation 
and Resource Surveillance, provided assistance that facilitated the successful completion of the project. Smith Ezra of Pingelap and Don "Arnie" Arnold, a USGS employee, assisted in all aspects of the field work. Klaus Wyrtki of the Tropical Ocean Global Atmosphere Sea Level Center at the University of Hawaii provided tide data.

\section{METHODS OF STUDY}

The methods used to describe the ground-water resources of Pingelap Island, Pingelap Atoll were constrained by available transportation to and from the atoll, as well as, on the atoll itself. To reach the isolated atoll of Pingelap, equipment and supplies must be shipped by the interisland (field trip) shipping service that calls on the island only once every four to six weeks. All equipment and supplies must be portable enough to be hand-carried because there are no docking facilities or vehicles on the island.

\section{Reconnaissance}

A reconnaissance of Pingelap Island was done in December 1986 to collect baseline information needed for the identification of a potential fresh ground-water resource, and to begin the assessment of ground water as an alternative water supply. Twenty existing dug wells were located, described, and sampled for temperature, specific conductance, and chloride concentration (these are included in figure 3 ). Five of the 20 dug wells were sampled to determine major constituent ion, nitrate, and phosphate concentrations.

\section{Installation of Driven-Well Network}

A network of 25 driven wells, comprising 10 clusters, was installed in July 1988 to determine and monitor the thickness of fresh ground water beneath Pingelap Island (fig. 3). The wells were installed, generally in clusters of three, at depths bracketing the lower limit of potable water. The driven wells consist of 2-in.-diameter galvanized steel pipe and well points with 24 -in.long screens. Pipe was added in 5- or 6-ft sections by threaded couplings and driven by a 100-pound drop hammer until the screen reached the depth desired or the deepest depth attainable. A surge block was used to develop the wells.
Table 1. Driven-well construction information, Pingelap Island, Pingelap Atoll

[Well no.: Letter is cluster-site designation; number is depth of well below land surface.]

\begin{tabular}{|c|c|c|}
\hline Well no. & $\begin{array}{l}\text { Screened interval } \\
\text { (depth in feet below } \\
\text { land surface) }\end{array}$ & Comments \\
\hline A-18 (1) & $15.5-17.5$ & dry at low tide \\
\hline A-18 (2) & $15.5-17.5$ & dry at low tide \\
\hline B-13 & $10.5-12.5$ & \\
\hline B-18 & $15.5-17.5$ & \\
\hline B-31 & $28.5-30.5$ & \\
\hline B-34 & $31.5-33.5$ & \\
\hline C-13 & $10.5-12.5$ & \\
\hline C-18 & $15.5-17.5$ & \\
\hline C-23 & $20.5-22.5$ & \\
\hline D-15 & $12.5-14.5$ & \\
\hline D-30 & $27.5-29.5$ & \\
\hline D-54 & $51.5-53.5$ & \\
\hline E-14 & $11.5-13.5$ & \\
\hline E-30 & $27.5-29.5$ & \\
\hline $\mathrm{E}-40$ & $37.5-39.5$ & \\
\hline F-20 & $17.5-19.5$ & hand pump installed \\
\hline F-39 & $36.5-38.5$ & \\
\hline F-57.5 & $55.5-57.0$ & \\
\hline G-13 & $10.5-12.5$ & bent well point, pumped sand \\
\hline H-14 & $11.5-13.5$ & \\
\hline $\mathrm{I}-20$ & $17.5-19.5$ & hand pump installed \\
\hline $\mathrm{I}-40$ & $37.5-39.5$ & \\
\hline $\mathrm{I}-53.5$ & $51.0-53.0$ & \\
\hline $\mathrm{J}-8$ & $5.5-7.5$ & dry at low tide \\
\hline J-9 & $6.5-8.5$ & dry at low tide \\
\hline
\end{tabular}

A nearly ubiquitous hard layer at or near the water table along the margin of the island restricted the location of driven-well clusters to the perimeter of the taro patch. Driven-well clusters A, G, H, and J are within $500 \mathrm{ft}$ of the island margin and are at locations where the deepest depth attainable was the hard layer found at or near the water table. Construction information for the driven wells, including depth and screened interval, is provided in table 1.

The use of driven wells with well points allows the determination of water level and water quality at specific depths without disrupting the natural chlorideconcentration distribution in the lens-shaped freshwater 


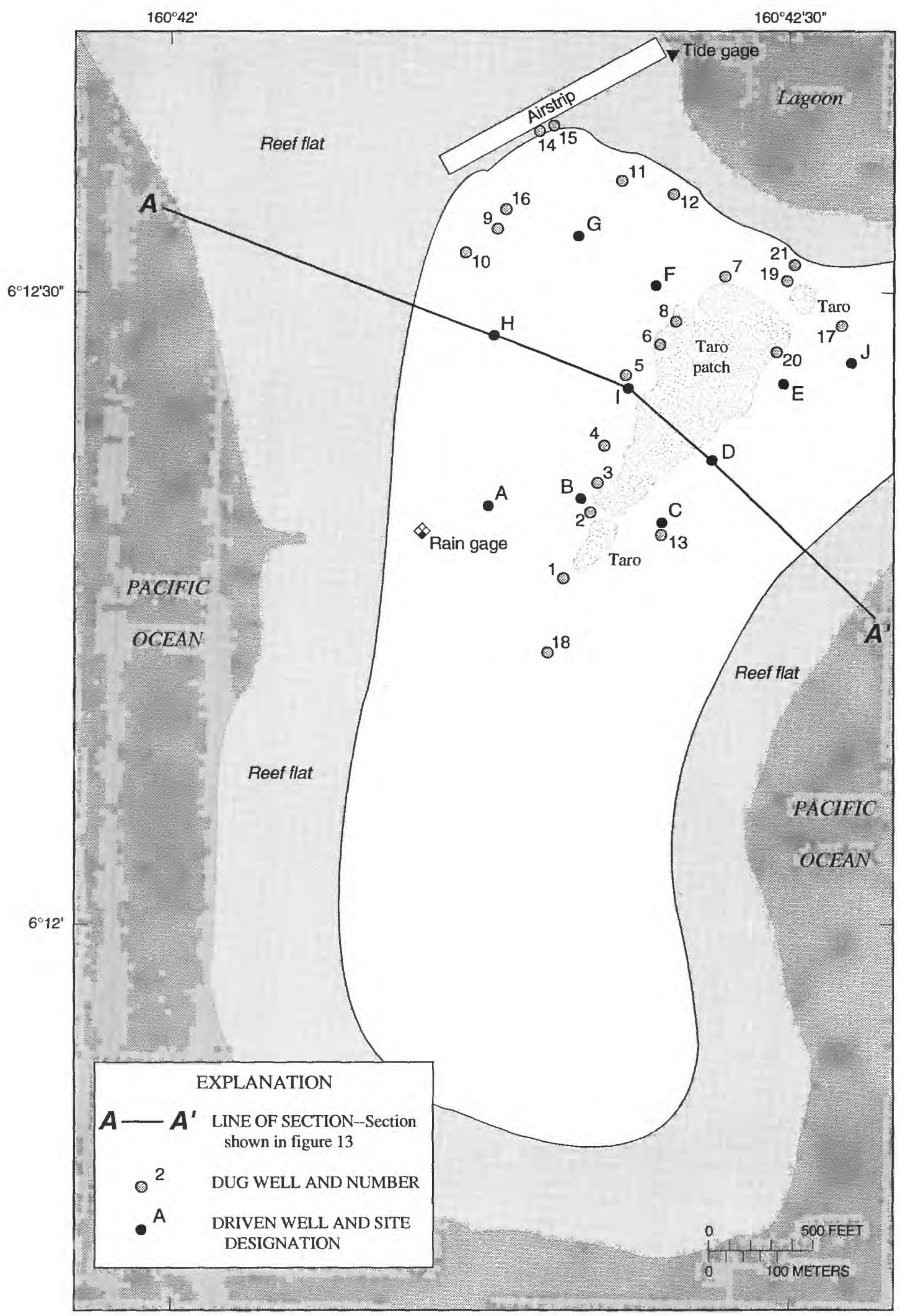

Figure 3. Location of dug wells, driven wells, and line of section, Pingelap Island, Pingelap Atoll. 
body. Use of continuously perforated wells on Enewetak (Buddemeier and Holladay, 1977) and Kwajalein (Hunt and Peterson, 1980) Atolls in the Marshall Islands allowed the movement of underlying saltwater into the freshwater section of the well by means of tideinduced mixing thereby obscuring the natural chloride concentration in the freshwater lens.

\section{Surface Geophysical Survey}

Electromagnetic profiling was done in August 1989 to interpolate freshwater-thickness data between driven-well clusters and ultimately to areally map the thickness of freshwater. The electromagnetic-profiling procedure used is based on a well-established surface geophysical method (McNeill, 1980a; Stewart, 1982; Stewart, 1988; Anthony, 1992). In this method a magnetic field applied at the surface induces electrical currents in the earth. These currents generate a secondary magnetic field that is measured and used to obtain terrain-conductivity readings. Factors that affect terrain conductivity are (1) porosity, (2) pore fluid conductivity, (3) pore surface area, (4) degree of saturation, (5) temperature, and (6) presence of clays with moderate to high cation exchange capacity.

The instrument used in this study was the dual loop Geonics EM 34-3XL terrain-conductivity meter. Survey transect lines of about 20 stations were established along four footpaths that cross the width of the island. Six terrain-conductivity readings consisting of three coil spacings (10,20, and 40 meters) and two coil orientations (horizontal and vertical coplanar) were made at each station providing four different exploration depths. In the vicinity of driven-well clusters, the electromagnetic-interpreted interface depth was calibrated with chloride-concentration data derived from the drivenwell clusters. The depth to the electromagnetic-interpreted interface was calculated from the field data using the computer program EMIX 34 (Interpex, 1988). EMIX 34 is a forward and inverse modeling program designed to obtain a quantitative interpretation of terrain-conductivity data in terms of a layered-earth solution.

\section{Measurement of Rainfall}

Daily rainfall measurements were made with an 8in.-diameter rain gage by a local U.S. National Oceanic and Atmospheric Administration observer. The station was established in November 1985 and is located on the western side of Pingelap Island (fig. 3). These measurements were used to identify seasonal variations in rainfall and to relate changes in rainfall with changes in storage of freshwater within the lens.

\section{Collection of Water Samples}

Samples were collected for analysis of chloride concentration from all wells in September 1988, August 1989, and March 1990. Samples collected from driven wells were used to develop relative-salinity depth profiles needed to estimate the thickness of freshwater. Samples collected from shallow dug wells were used to describe the chloride-concentration distribution in ground water at the water table as a means of defining the lateral extent of the fresh ground-water body.

To determine the chemical characteristics of water at each site, one sample from each well was analyzed for major constituent cations and anions, and for inorganic nutrients. The samples were collected in March 1990. Samples from driven wells were collected using an all-plastic, hand-operated positive displacement pump to avoid aeration-induced concentration changes of the major ionic constituents. The wells were pumped until the electrical conductivity of the pumped water stabilized, indicating that water in the casing had been completely purged, before collecting the water sample. Dip samples were collected from the dug wells. Temperature, $\mathrm{pH}$, total alkalinity, and specific conductance were determined in the field. Samples for major ion and nutrient analysis were preserved for laboratory determinations at the University of Hawaii. Results of these analyses are shown in tables 2, 3, and 4 at the end of the report.

\section{Measurement of Water Levels}

Continuous water levels were obtained from selected dug and driven wells with a chart recorder used in conjunction with an electric water-level sensor. Measurements were made for 2 days to relate ground-water responses to tidal fluctuations. A continuous recording tide gage was installed at the lagoon end of the Pingelap airstrip for 7 days to relate Pingelap tide data with tide data from a gage on Pohnpei that is maintained by the Tropical Ocean Global Atmosphere Sea Level Center at the University of Hawaii. The location of the lagoon tide gage is shown in figure 3 . 


\section{Slug (Bail) Tests}

Slug (bail) tests are a quick and inexpensive field method for obtaining localized, horizontal hydraulicconductivity values of aquifer material with a single well. Slug (bail) tests were made in October 1989 by lowering the water level in driven wells by short-duration pumping with a hand pump and attached suction hose that was rapidly removed from the well after the water level had lowered 10 to $20 \mathrm{ft}$. The recovery of the water level was timed with a stopwatch and measured with a hand-held electric measuring tape.

\section{HYDROGEOLOGY}

The following sections describe the general features of atolls and the hydrologic units that form atoll islands. The last two sections describe a conceptual ground-water flow model for atoll islands, and the hydraulic characteristics of the sediments that comprise Pingelap Island.

\section{General Atoll Features}

Atolls are sub-circular reefs composed of a resistant framework of calcareous skeletons enclosing a lagoon from the open sea. The reef structure is constantly scoured and planed off by wave action and dissected by seaward-trending surge channels. The reef framework commonly is highly porous. In some cases estimates of as much as 50 percent porosity have been cited (Selley, 1970). Islets are composed primarily of unconsolidated carbonate sediments and sit atop the reef structure. A schematic diagram of an atoll is shown in figure 4.

An atoll is derived from a fringing reef around a volcanic island. As the island sinks, the reef organisms build upward in an attempt to keep pace with the relative rise in sea level. The volcanic island is eventually submerged, leaving only the reef and the enclosed lagoon, forming an atoll. As part of the environmental studies made in the Marshall Islands in connection with atomic-bomb testing, the U.S. Navy drilled a series of deep test holes on Enewetak Atoll. Two of the test holes went through a 3,900-ft cap of shallow-water reef limestone and bottomed in basalt. The age of fossils in the deepest limestone is Eocene, indicating that Enewetak Atoll is the top of a coralline accumulation that began growing upward about 60 million years ago (Schlanger, 1963).

Sea level rises during interglacial periods and falls during glacial periods. The cycle of sea-level rise and fall has been repeated several times in the past million years. These fluctuations affected carbonate depositional sequences on oceanic islands worldwide. During the Pleistocene epoch, atolls were affected by four or more such fluctuations. With each drop in sea level, as much as 300 vertical feet of reef and lagoonal sediments were exposed to subaerial weathering and erosion. The subsequent sea-level rise caused accumulation of new reef and lagoonal sediments over each preceding erosional unconformity (Schlanger, 1963). Pleistocene unconformities have been reported in six atolls of the central Pacific Ocean: Bikini, Enewetak, Majuro, Mururoa, Midway, and Tawara (Emery and others, 1954; Ladd and Schlanger, 1960; Anthony and others, 1989; Lalou and others, 1966; Ladd and others, 1970; and Marshall and Jacobson, 1985, respectively). The unconformities were caused by alternation between growth during interglacial high stands of sea level and erosion during glacial lowering of sea level. Holocene sediments above the 120,000-year unconformity at depths of 26 to $32 \mathrm{ft}$ at Enewetak and Bikini are generally little more than 6,000 years old (Tracey and Ladd, 1974).

\section{Hydrogeologic Units}

The hydrogeologic framework of an atoll island can be considered to consist of four units (fig. 5). The first unit is the island itself. The island intercepts rainfall; a fraction of the rainfall is lost to evapotranspiration, and the remainder infiltrates the island's sediments to form a lens of freshwater. Because of the high permeability of the soils, there is no surface runoff.

The second unit is the reef-flat plate. The reef-flat plate is extremely well indurated and forms a stable foundation on which the island's sediments accumulate. It probably is no more than 10 to $15 \mathrm{ft}$ thick and thins from the reef front lagoonward, pinching out at some distance beneath the island. The permeability of the reef-flat plate is less than that of the underlying unconsolidated sediments. The reef-flat plate at Pingelap extends beneath much of the island and acts as a confining layer, impeding recharge. Elsewhere, the lens is unconfined.

The third unit consists of unconsolidated deposits of Holocene age. The deposits are composed of silt- to 


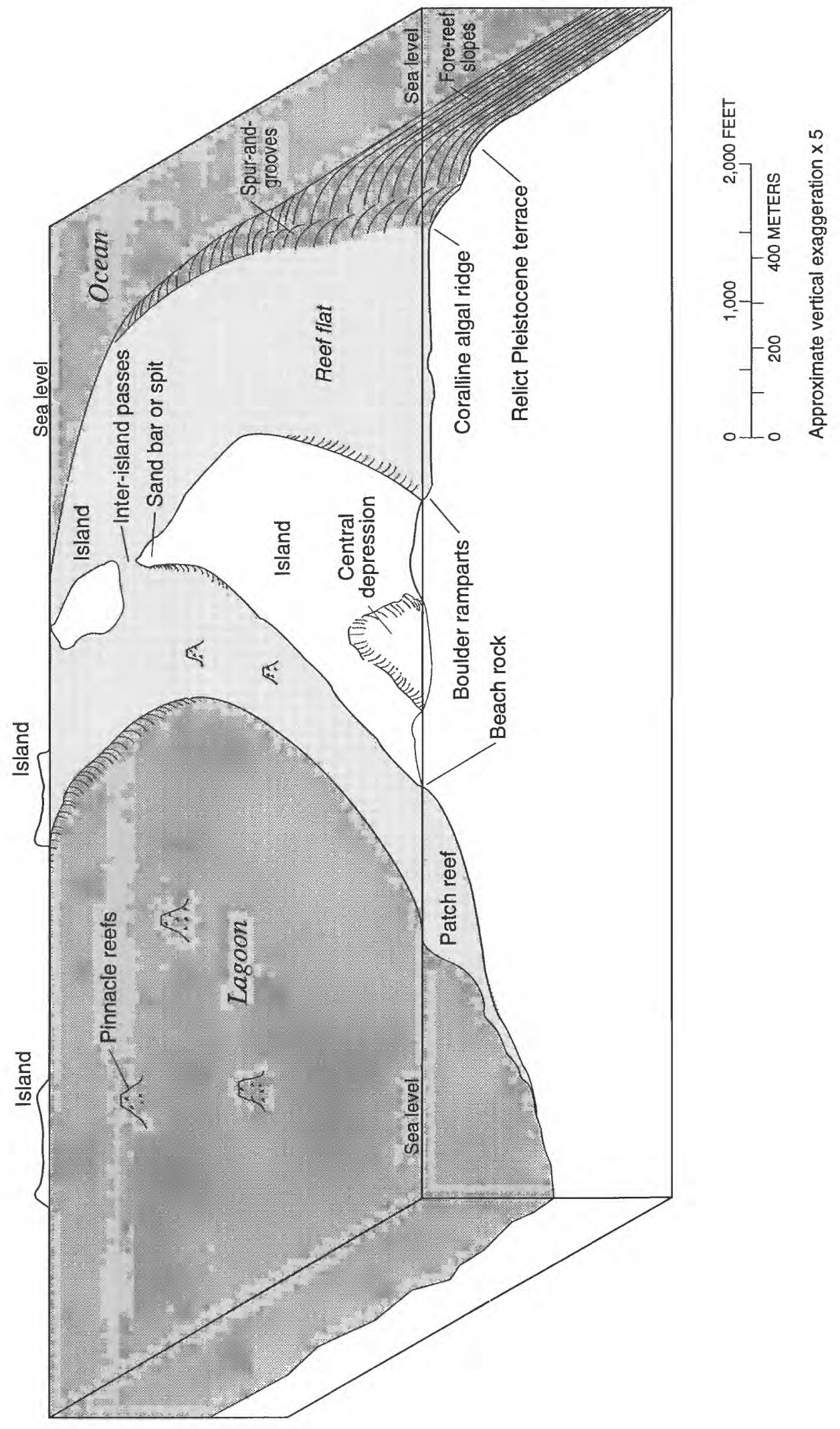

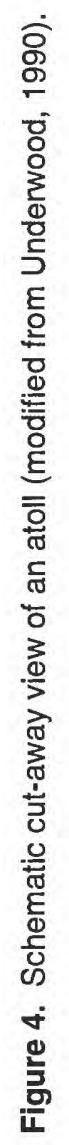




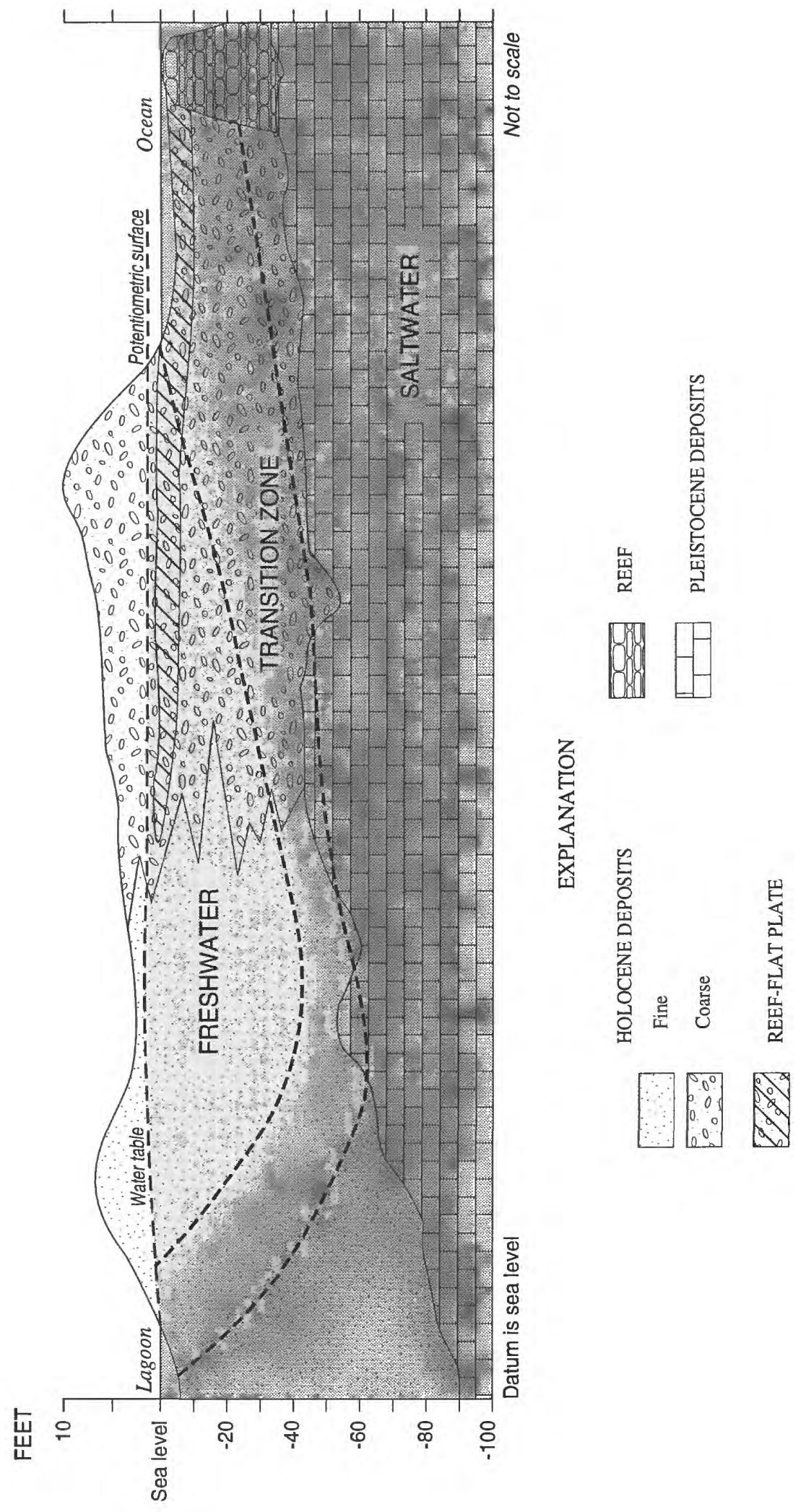

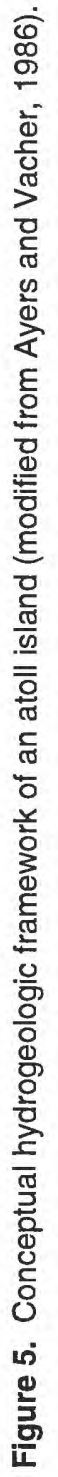


gravel-sized fragments of foraminifera, Halimeda and coral. Layering and lateral gradation of these back-reef and marginal-lagoon deposits affect the occurrence and flow of freshwater in the Holocene deposits. Analyses of the rate at which tidal fluctuations propagate into the ground-water system and analyses of sediment grainsizes indicate a general areal variation in permeability across an atoll island: relatively high values for sediments bordering the ocean, and lower values for sediments adjacent to the lagoon (Ayers and Vacher, 1986; Marshall and Jacobson, 1985; Anthony and others, 1989). The presence of lower permeability sediments adjacent to the lagoon results in a freshwater lens that is thicker on the lagoon-side of an atoll island.

The fourth unit consists of highly permeable deposits of Pleistocene age that underlie the Holocene deposits. The primary skeletal material of the Pleistocene deposits is similar to that of the Holocene deposits. The contact between the Holocene and Pleistocene deposits is typically at depths of 50 to $80 \mathrm{ft}$ below sea level and represents a pronounced permeability contrast in which the Pleistocene deposits are more permeable than the Holocene deposits (Tracey and Ladd, 1974; Marshall and Jacobson, 1985; Anthony and others, 1989). The permeability contrast between the two units has been estimated to be at least an order of magnitude and has been attributed to the development of secondary porosity when the Pleistocene deposits were emergent during low sea-level stands. The highly permeable Pleistocene deposits at Majuro were found to contain seawater and thin the transition zone beneath the part of the freshwater lens that is sufficiently thick to extend down to the Pleistocene deposits (Anthony and others, 1989).

A conceptual model of the hydrogeology of Pingelap Island was developed from near-surface observations combined with published descriptions of the hydrogeology of other atoll islands in the western Pacific (fig. 5). This model incorporates a dual-aquifer system that consists of surficial Holocene deposits overlying more permeable Pleistocene deposits (Buddemeier and Holladay, 1977; Ayers and Vacher, 1986; Anthony and others, 1989; Underwood, 1990). Layering and lateral gradation of back-reef and marginallagoon deposits affect the occurrence and flow of freshwater within the Holocene deposits. Core drilling was not done on Pingelap Island; however, results for Deke indicate that the atoll has undergone similar depositional and tectonic histories, and sea-level changes as other atolls in the western Pacific. Therefore a generalized conceptual hydrogeologic model of atoll islands should apply to the island of Pingelap.

\section{Conceptual Ground-Water Flow Model}

Atoll islands are composed of permeable sediments that are readily infiltrated by rainfall. If the infiltration from rainfall is sufficiently great, a lens of freshwater that floats on saline ground water forms, somewhat like an iceberg floating in the ocean (fig. 6). Freshwater moves downward and then radially outward, toward the coastal margins of the island to discharge into the sea. Some of the freshwater mixes with underlying saltwater to form a transition zone of mixed, or brackish water. The freshwater, which has a density of $1.000 \mathrm{~g} / \mathrm{cm}^{3}$, displaces the underlying saltwater, which has a density of about $1.025 \mathrm{~g} / \mathrm{cm}^{3}$. The depth of this lens is about 40 times the elevation of the water table above sea level. This 40:1 ratio is known as the Ghyben-Herzberg relation. The actual thickness of freshwater is influenced by the recharge and discharge rates, size and shape of the island, and the hydraulic characteristics of the hydrogeologic units. Variations in the thickness of the transition zone are affected by mixing induced by tidal fluctuations, variations in recharge and pumpage, and the rate and direction of groundwater flow.

In most atoll islands, the hydraulics of the groundwater system are characterized by long-term horizontal flow that is driven by recharge, and short-term vertical fluctuations that are driven by semi-diurnal tides. Tidal fluctuations enhance mixing within the transition zone and ultimately reduce the potable part of the freshwater lens. In general, the freshwater lens is thicker on the lagoon-side of an atoll island because of the lower permeability of lagoon-side sediments relative to oceanside sediments (Cox 1951; Hamlin and Anthony 1987). Numerical computer simulation of this conceptual ground-water flow model has been done by Herman and others (1986), Hogan (1988), Griggs (1989), and Underwood (1990).

\section{Hydraulic Characteristics}

The hydraulic characteristics of the Holocene deposits at Pingelap were estimated by analyzing tidal responses and slug (bail) tests. Tidal-response analysis 


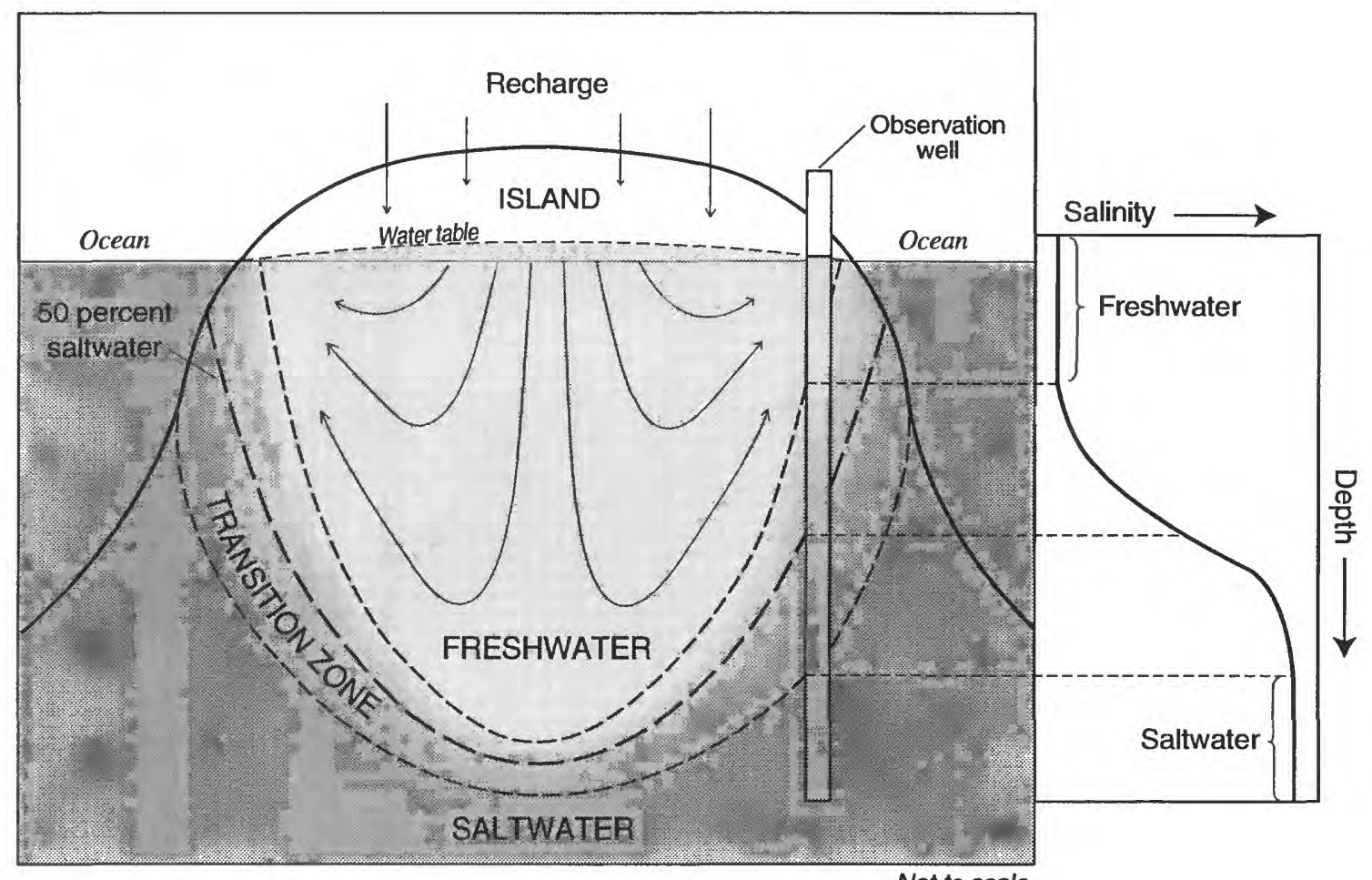

Not to scale

Figure 6. Schematic section of freshwater lens with transition zone, and graph showing relation of salinity and depth (modified from Vacher, 1974).

was used to qualitatively assess the permeability of aquifer material between a given well and the ocean. Slug bail-test analysis was used to quantitatively determine localized, horizontal hydraulic-conductivity values of aquifer material in the vicinity of a single well. Because of the difference in scale measured by tidal response and slug (bail) tests, it is not possible to correlate the results from these analyses.

Tidal efficiency is expressed as the ratio of waterlevel fluctuation in a well to the tidal fluctuation in the ocean. Similarly, tidal lag is the time difference between ocean tide and corresponding fluctuation in ground-water level. The results from tidal response and slug (bail) tests can be affected by the clogging of the well screen with fine grained sediments during the construction of a driven well. All wells were developed by surging to remove fine-grained sediments and ensure that water levels in wells represent water levels in the aquifer. It is not possible to remove all of the finegrained sediments. The reduction in well efficiency due to the clogging of a well screen will have a greater effect on slug (bail) test results than on tidal-response data because the rate of change in water level is much larger during a slug (bail) test than during a tidal-response test.

Tidal-lag and tidal-efficiency data from Bikini, Enewetak, Kwajalein, and Majuro Atolls have been analyzed in terms of a dual-aquifer system consisting of surficial Holocene deposits overlying more permeable Pleistocene deposits (Underwood, 1990). The tidal-lag and tidal-efficiency data from these atolls indicate that patterns of ground-water flow are affected by the permeability contrast between the Holocene and Pleistocene deposits, and sea-level fluctuations that impose stresses from both the lagoon and the ocean-side of the island. Increasing tidal efficiencies with depth indicate that the permeability of the Pleistocene deposits is much greater than that of the overlying Holocene deposits. On Majuro, tidal lags on the order of 15 to 30 minutes and tidal efficiencies near 90 percent recorded just above the Holocene/Pleistocene contact indicate that these tidal signals have undergone very little attenuation as they propagate through the Pleistocene deposits (Anthony and others, 1989). It is likely that the tidal signal in an atoll island is propagated vertically within the Holocene 
Table 5. Tidal-response data, Pingelap island, Pingelap

Atoll

[hr:min, hours and minutes; ND, not determined]

Well no.: Letter is cluster-site designation, and number is depth of well below land surface.

Tidal efficiency: ratio of water-level fluctuation in a well to the tida

fluctuation in the ocean.

Tidal lag: time difference between ocean and ground-water signals.

\begin{tabular}{|c|c|c|}
\hline Well no. & Tidal efficiency & $\begin{array}{c}\text { Tidal lag } \\
\text { hr:min }\end{array}$ \\
\hline B-13 & 0.21 & $1: 00$ \\
\hline B-18 & 0.37 & $0: 20$ \\
\hline B-34 & 0.76 & $0: 15$ \\
\hline C-13 & 0.25 & $2: 50$ \\
\hline C-18 & 0.24 & $2: 10$ \\
\hline C-23 & 0.35 & $1: 45$ \\
\hline D-15 & 0.07 & $2: 15$ \\
\hline D-30 & 0.29 & 1:05 \\
\hline D-54 & 0.05 & $2: 50$ \\
\hline E-14 & 0.36 & $0: 50$ \\
\hline E-30 & 0.60 & $0: 25$ \\
\hline$E-40$ & 0.54 & $0: 40$ \\
\hline F-39 & 0.35 & $0: 20$ \\
\hline F-57.5 & 0.01 & $3: 20$ \\
\hline $1-40$ & 0.02 & $2: 20$ \\
\hline |-53.5 & 0.01 & ND \\
\hline
\end{tabular}

deposits, because the depth to the highly permeable Pleistocene deposits is relatively small compared to the width of the island.

On Pingelap, tidal-lag and tidal-efficiency data do not show a systematic decrease and increase with depth, respectively, indicating that ground-water flow patterns are not affected by the assumed permeability contrast between Holocene and Pleistocene deposits (table 5 and fig. 7). Tidal efficiencies increase with depth from an average of 26 percent at an interval of 10 to $22 \mathrm{ft}$ below land surface to an average of 46 percent at an interval of 28 to $40 \mathrm{ft}$ below land surface; however, between 50 to $60 \mathrm{ft}$ below land surface, the tidal efficiencies drop to an average of 2 percent. Slug tests from driven wells at 50 to $60 \mathrm{ft}$ below land surface indicate that hydraulic conductivities range from 0.1 to $0.3 \mathrm{ft} /$ day at this horizon. Without subsurface geologic information and relying on the dual-aquifer-system model, it can only be inferred that a low-permeability layer, perhaps lagoonal muds at depth within the Holocene deposits or an impermeable rind of a solution-altered Pleistocene soil zone, may retard the vertical propagation of the tidal signal at Pingelap Island.

Calculated hydraulic conductivities for Pingelap range from less than 0.1 to $51 \mathrm{ft} /$ day (fig. 8). Recovery times for the slug (bail) tests ranged from 2 minutes to greater than 4 hours. The tests were analyzed using the method of Hvorslev (1951) and the shape factor presented by Freeze and Cherry (1979). This analysis assumes a homogeneous, isotropic, infinite medium in which both soil and water are incompressible. The calculated hydraulic-conductivity values for Pingelap are consistent with those obtained from other atoll islands; 0.3 to $200 \mathrm{ft} /$ day (Underwood, 1990). Figure 8 shows that, in general, the calculated hydraulic conductivities decrease with depth, indicating that the screen of a driven well may become progressively clogged the deeper the well is driven. To fully understand the complexities of subsurface layering and the effect of layering on the occurrence and flow of ground water in the Holocene deposits, core samples of these deposits must be collected; however, without an efficient and cost-effective means of obtaining core samples on a remote island, this cannot be accomplished.

\section{GROUND-WATER RESOURCES}

The following sections describe recharge to, and the occurrence, quantity, and quality of fresh ground water beneath Pingelap Island. Estimates of water demand and sustainable yield of the ground-water resource, development alternatives, and the need for additional data are discussed.

\section{Recharge}

A water balance based on regional climatic data was used to estimate the average annual recharge to the freshwater lens at Pingelap. The components of the water balance are rainfall, surface-water runoff, evapotranspiration, and ground-water recharge. Because there is no surface-water runoff on atoll islands, the rate of recharge to the freshwater lens at Pingelap is equal to rainfall minus evapotranspiration. For Pingelap, no 


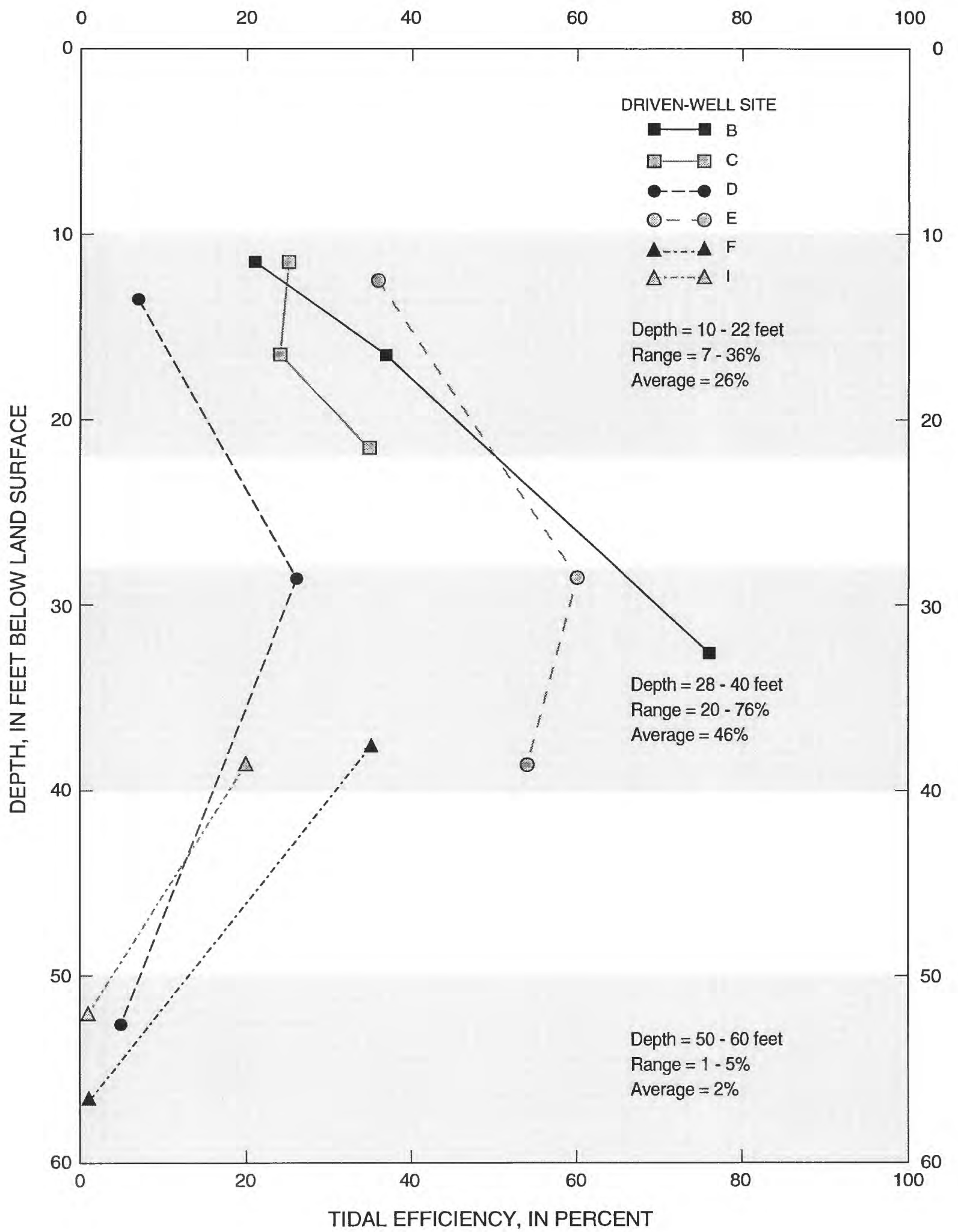

Figure 7. Variation in tidal efficiency with depth for selected driven-well sites, Pingelap Island, Pingelap Atoll. 


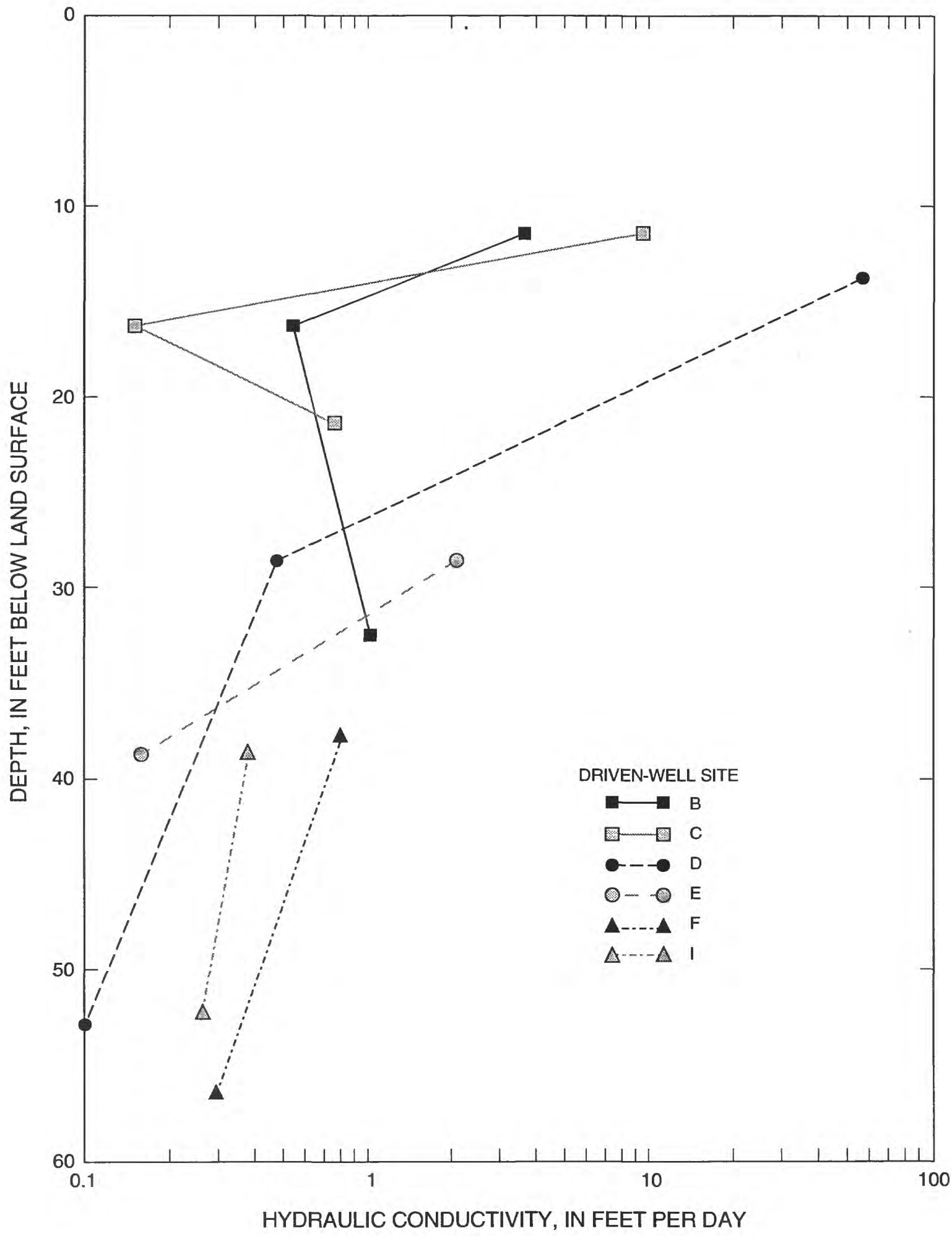

Figure 8. Variation in hydraulic conductivity with depth for selected driven-well sites, Pingelap Island, Pingelap Atoll. 
measurements have been made for any component of the water balance except rainfall.

The mean annual rainfall at Pingelap is 162 in. with a standard deviation of $9.4 \mathrm{in}$. This data is based on daily rainfall totals recorded by a local U.S. National Oceanic and Atmospheric Administration observer since November 1985. The data consist of 54 monthly and 4 annual totals (table 6). Figure 9 shows that on average, rainfall is highest in December (16.14 in.) and lowest in February (7.52 in.). There is no significant dry season.

A regional rainfall map of the western Pacific (Taylor, 1973) shows the average annual rainfall at Pingelap to be 200 in. (fig. 10), which is significantly higher than the 162 in. of mean annual rainfall recorded at Pingelap. The position of the 160 - and 200 -in. rainfall line shown in figure 10 is probably the result of orographic effects reflected in the long-term rainfall records of the high volcanic islands of Kosrae and Pohnpei, which are located to the southeast and northwest of Pingelap, respectively. A comparison of monthly rainfall totals for Pingelap and Pohnpei shows little or no correlation; the lack of correlation indicates that Pingelap is not influenced by orographic effects, as on Pohnpei, and that the average annual rainfall at Pingelap is probably closer to 160 in. than to 200 in. The longterm average annual rainfall at Pingelap is therefore assumed to be $160 \mathrm{in}$. because it provides a more conservative estimate of ground-water recharge in the following analysis.

Evapotranspiration, a term used to describe evaporation of rainfall and transpiration of soil moisture by plants, was not measured at Pingelap. It can be estimated, however, by evaluating previous studies in the western Pacific. In a study of the Chuuk (Truk) Islands, Takasaki (1989) developed a relation between mean annual rainfall and evapotranspiration on the basis of data from the islands of Guam, Johnston, and Yap and determined that the evapotranspiration loss was about 50 percent of the rainfall at Chuuk. The islands of Chuuk and Pingelap lie within an elongate belt of greater than 120 in. of annual rainfall that extends eastward beyond Majuro and westward to Palau (fig. 9). Nullet (1987) estimated ground-water recharge rates for Pacific atolls under average climatological conditions and rainfall as shown in Taylor (1973). The method assumes that climatological conditions over atolls are similar to those over the open ocean. Nullet (1987) concluded that

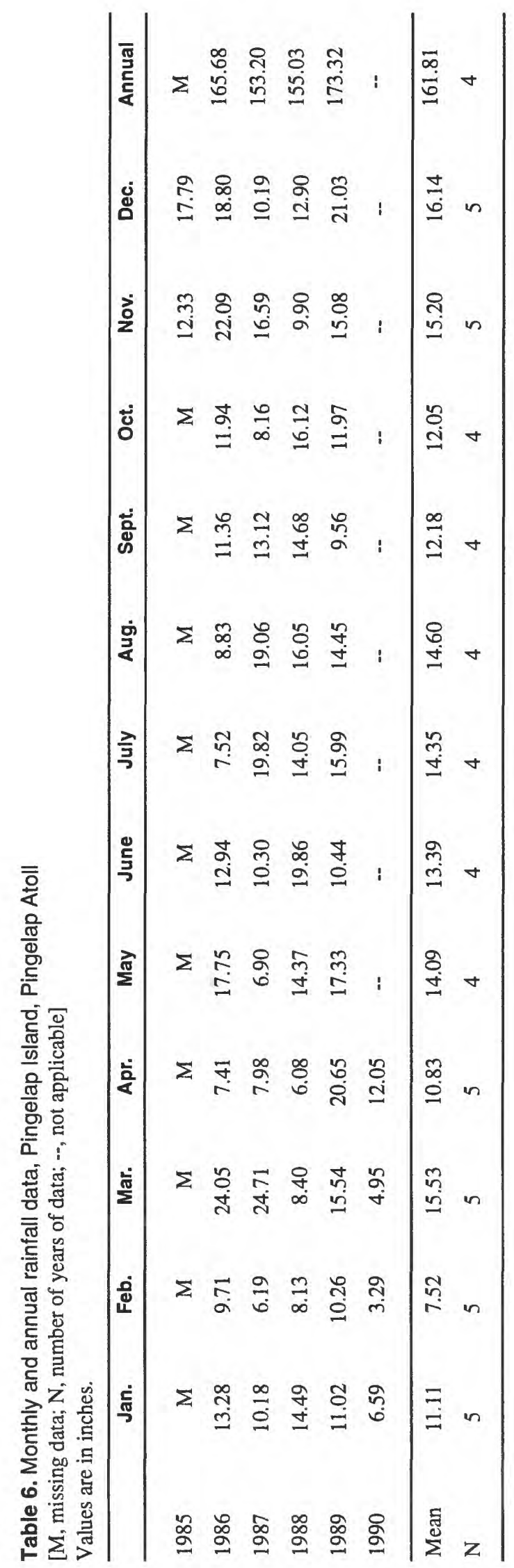




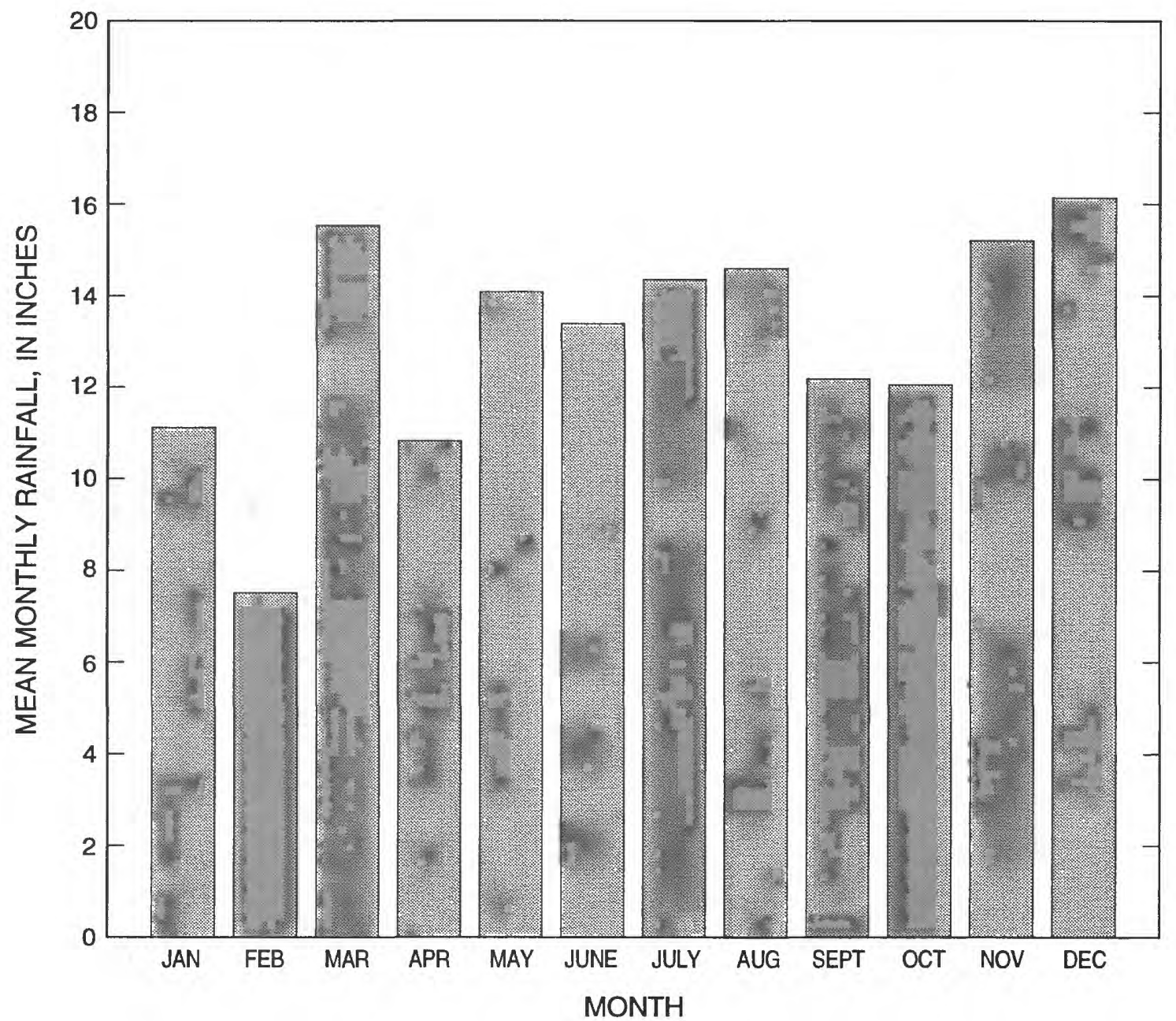

Figure 9. Mean monthly rainfall, based on intermittent monthly totals from November 1985 through April 1990, Pingelap Island, Pingelap Atoll.

ground-water recharge for Pingelap is about 50 percent of the rainfall. The 50 percent recharge rate also compares favorably with estimates by Hunt and Peterson (1980) and Hamlin and Anthony (1987) for Kwajalein and Majuro Atolls, respectively. Evapotranspiration at Pingelap is, therefore, estimated to be 50 percent of rainfall.

To provide a conservative estimate of groundwater recharge it is assumed that the long-term average annual rainfall at Pingelap is $160 \mathrm{in}$. and evapotranspiration losses are 50 percent of the average annual rainfall. Given these assumptions, ground-water recharge at Pingelap is $80 \mathrm{in} / \mathrm{yr}$. This rate of recharge over a freshwater lens catchment area of 38.6 acres $\left(6.03 \mathrm{mi}^{2}\right)$ underlain by at least $15 \mathrm{ft}$ of potable water results in an average daily recharge of 230,000 gallons. This is an average value; actual values would vary with rainfall and evapotranspiration.

\section{Occurrence}

The size and shape of the lens of freshwater at Pingelap is governed principally by recharge, hydraulic characteristics of the aquifer, and the size and shape of the island. The configuration of the lens was estimated using chloride-concentration data from the dug and driven wells. For the purposes of resource evaluation, the term freshwater nucleus is applied to the potable part of the ground-water body. The World Health Organization's (WHO) (1971) international standard for drinking water recommends a maximum permissible 


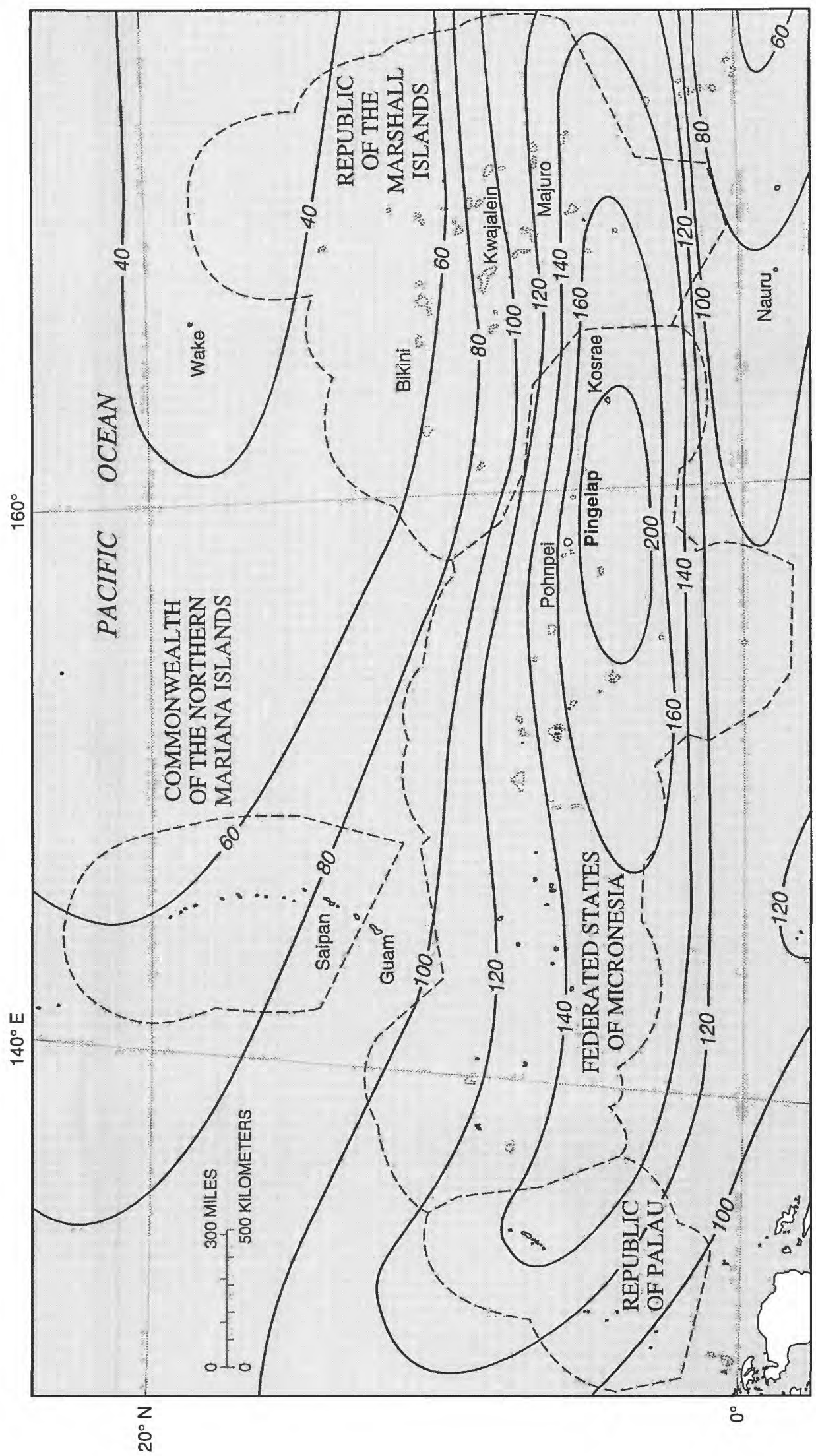

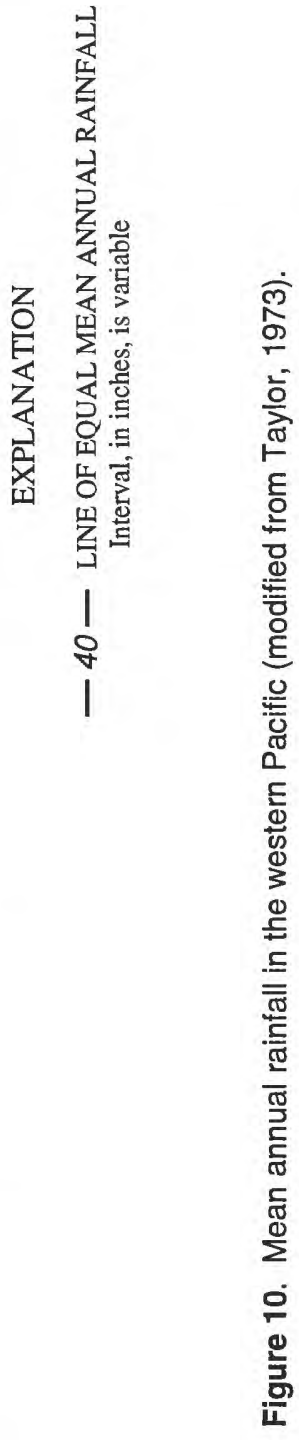


level of $600 \mathrm{mg} / \mathrm{L}$ for chloride; this criterion was adopted in this study for definition of the freshwater nucleus.

Samples from dug wells were collected to define the lateral extent of the freshwater lens. The chlorideconcentration values for ground water at the water table at Pingelap Island indicate that the freshest part of the ground-water body is located beneath the taro patch and between the taro patch and the airstrip (fig. 11).

Samples were collected from driven wells to determine the vertical distribution of chloride concentration and to develop relative-salinity profiles that can be used to calculate the thickness of the freshwater lens. A chloride-concentration-depth profile at the D-site shows the typical S-shaped curve (fig. 12). The nearly vertical left limb of the curve represents the nucleus of the freshwater lens. The chloride concentration rapidly increases with depth between points $\mathrm{A}$ and $\mathrm{B}$. Below point $\mathrm{B}$, the chloride concentration increases gradually with depth.

The driven-well clusters installed during the study allow for the determination of chloride concentration at specific depths without disrupting the natural chlorideconcentration distribution within the freshwater lens. In order to interpolate between specific depths, a consistent methodology was used. In this study, the pointchloride-concentration determinations are expressed as relative salinity in percent seawater. The relative salinity values are then plotted on probability paper against depth, permitting linear interpolation between points (Vacher, 1974). Relative salinity $(R S)$ is defined as

$$
R S=100 \frac{\left(C l-C l_{f}\right)}{\left(C l_{s}-C l_{f}\right)},
$$

where $\mathrm{Cl}$ is the chloride concentration in the water sample and $\mathrm{Cl}_{s}$ and $\mathrm{Cl}_{f}$, represent chloride concentrations in saltwater and freshwater, respectively.

It is assumed that the limit for chloride concentration in potable water is $600 \mathrm{mg} / \mathrm{L}$, which is equivalent to a relative salinity of 3.1 percent. The depth of the 600 $\mathrm{mg} / \mathrm{L}$ chloride-concentration contour was interpolated from relative-salinity graphs. These depths were then used to construct cross-sections of the freshwater nucleus on the basis of the position of the $600 \mathrm{mg} / \mathrm{L}$ chlorideconcentration contour. Figure 13 is a cross-section through the Pingelap freshwater lens showing lines of equal relative salinity. The 3.1 percent relative-salinity contour defines the base of the freshwater nucleus. The thickest part of the freshwater nucleus coincides with the area within and around the taro patch.

Information on the thickness and shape of the freshwater lens was also derived from the geophysical survey. The purpose of the geophysical survey was to interpolate lens-thickness data between driven-well clusters and areally map the thickness of freshwater. A three layered-earth solution that includes unsaturated, freshwater, and saltwater zones was used to obtain a quantitative interpretation of electromagnetic (terrainconductivity) data measured in the field.

The following assumptions are used when applying electromagnetic profiling methods and layered earth modeling to the mapping of freshwater lenses: (1) the earth consists of horizontal, infinite, homogeneous, and isotropic layers, (2) the conductivity of each layer is constant and changes abruptly at each boundary, (3) the deepest layer is assumed to have an infinite thickness, and (4) the water table is close to sea level (Anthony, 1992).

The first layer of the three-layer solution represents the unsaturated zone. The thickness of the first layer is assumed to be the elevation of land surface above sea level; this is reasonable considering the height of the water table above sea level on atoll islands is less than $3 \mathrm{ft}$. The second layer is the freshwatersaturated zone. The third layer is the saltwater-saturated zone, assumed to be infinite in thickness. A conductivity of $1.0 \mu \mathrm{mho} / \mathrm{m}$ is assumed for the unsaturated layer, because the contrast between the conductivity of the unsaturated layer and the freshwater layer is not large enough to be resolved (Kauahikaua, 1987). Conductivity values for the freshwater and saltwater layers, and thickness of the second layer, which represents the freshwater lens, were determined by inversion modeling of the electromagnetic (terrain-conductivity) data with the computer program EMIX 34.

The overall shape of the freshwater lens was adequately determined by use of electromagnetic profiling methods and layered earth modeling. The model applied includes the unsaturated zone, freshwater zone, and saltwater zone, but excludes the transition zone. Chloride-concentration data from driven wells indicate that the electromagnetic-interpreted interface is located in the upper part of the transition zone, where the chloride-concentration-depth profile shows a rapid increase with depth (fig. 12). Considerable variability 


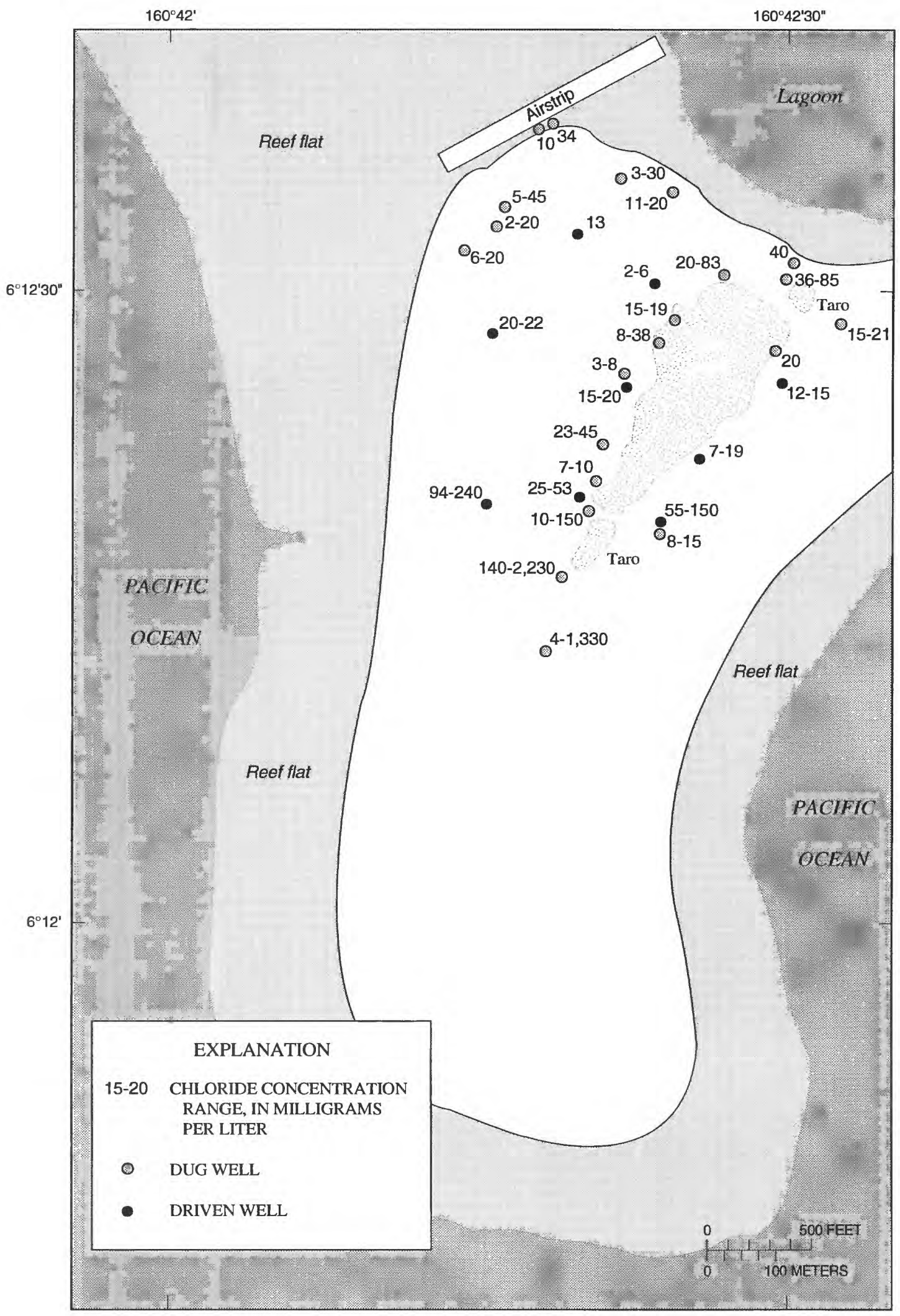

Figure 11. Chloride concentration of ground water at the water table, Pingelap Island, Pingelap Atoll. 


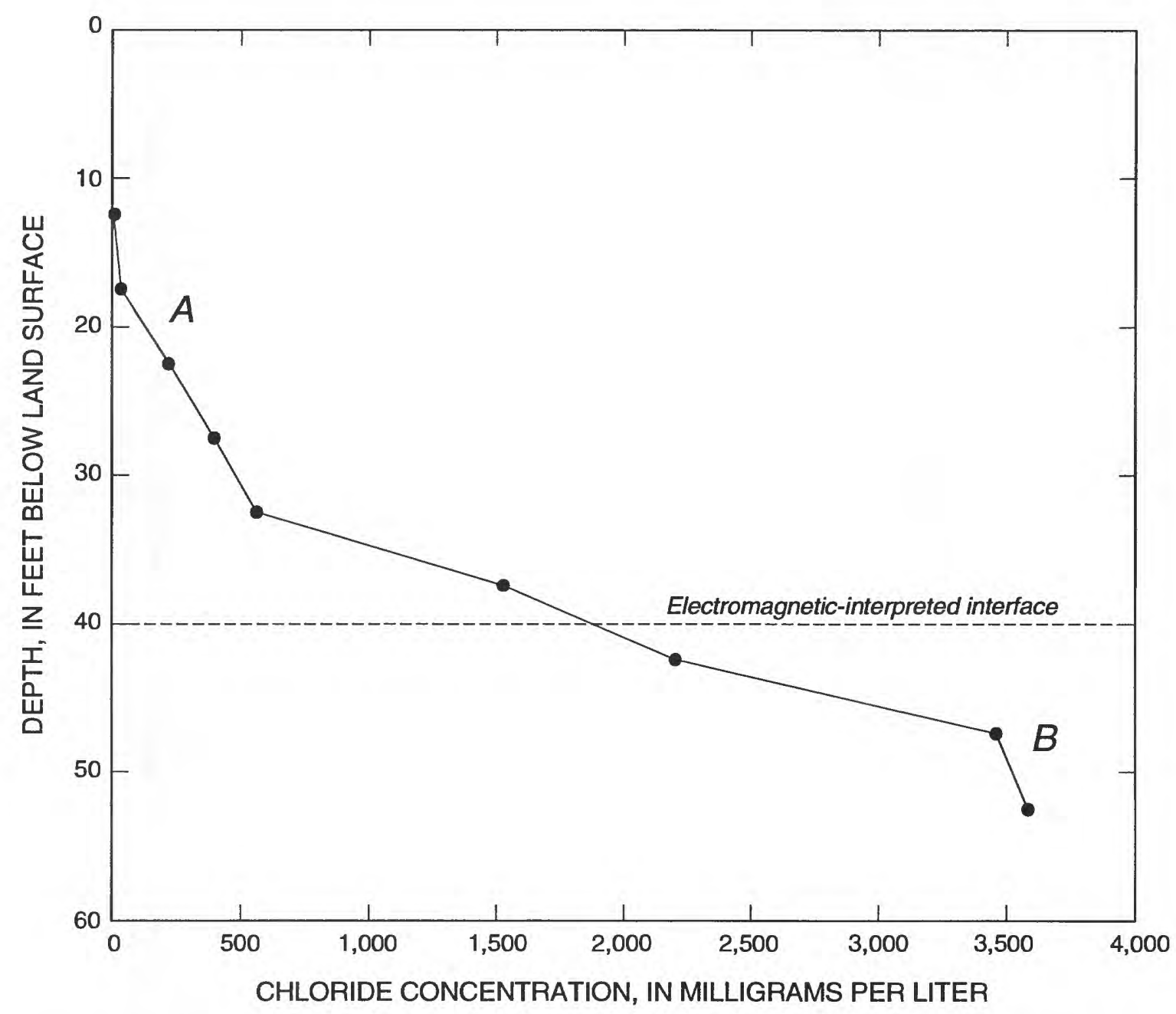

Figure 12. Variation in chloride concentration with depth at driven-well site D, Pingelap Island, Pingelap Atoll. S-shaped curve shows gradual increase in chloride concentration in the freshwater nucleus to point $A$, rapid increase between points $A$ and $B$, and gradual increase below point $B$.

was found at the island margins (fig. 14). Figure 15 shows the depth to the electromagnetic-interpreted interface below the water table in plan view as well as freshwater-thickness data at driven-well clusters. Electromagnetic profiling methods produce poor results where the island is underlain by brackish water rather than freshwater, because the layered-earth model used assumes that a freshwater layer exists and that there is a large contrast in conductivity between the freshwater and saltwater layers.

\section{Storage}

Storage of potable ground water in the Pingelap freshwater lens is estimated to be $384 \mathrm{Mgal}$ on the basis of the volume of the freshwater nucleus adjusted to account for porosity. Porosity was estimated to be 20 percent to provide a conservative estimate of the storage of ground water in unconsolidated carbonate sediments. The volume of the freshwater nucleus was approximated by combining chloride concentration and geophysical data to estimate the depth to the base of the freshwater nucleus in plan view (fig. 16).

Storage of potable ground water in a freshwater lens varies with rainfall recharge. Samples for analysis of chloride concentration were collected at three different times during a 19-month period to determine the response of the freshwater lens to variations in recharge from rainfall. Figure 17 shows plots of the variation in relative-salinity with depth at driven-well clusters and 


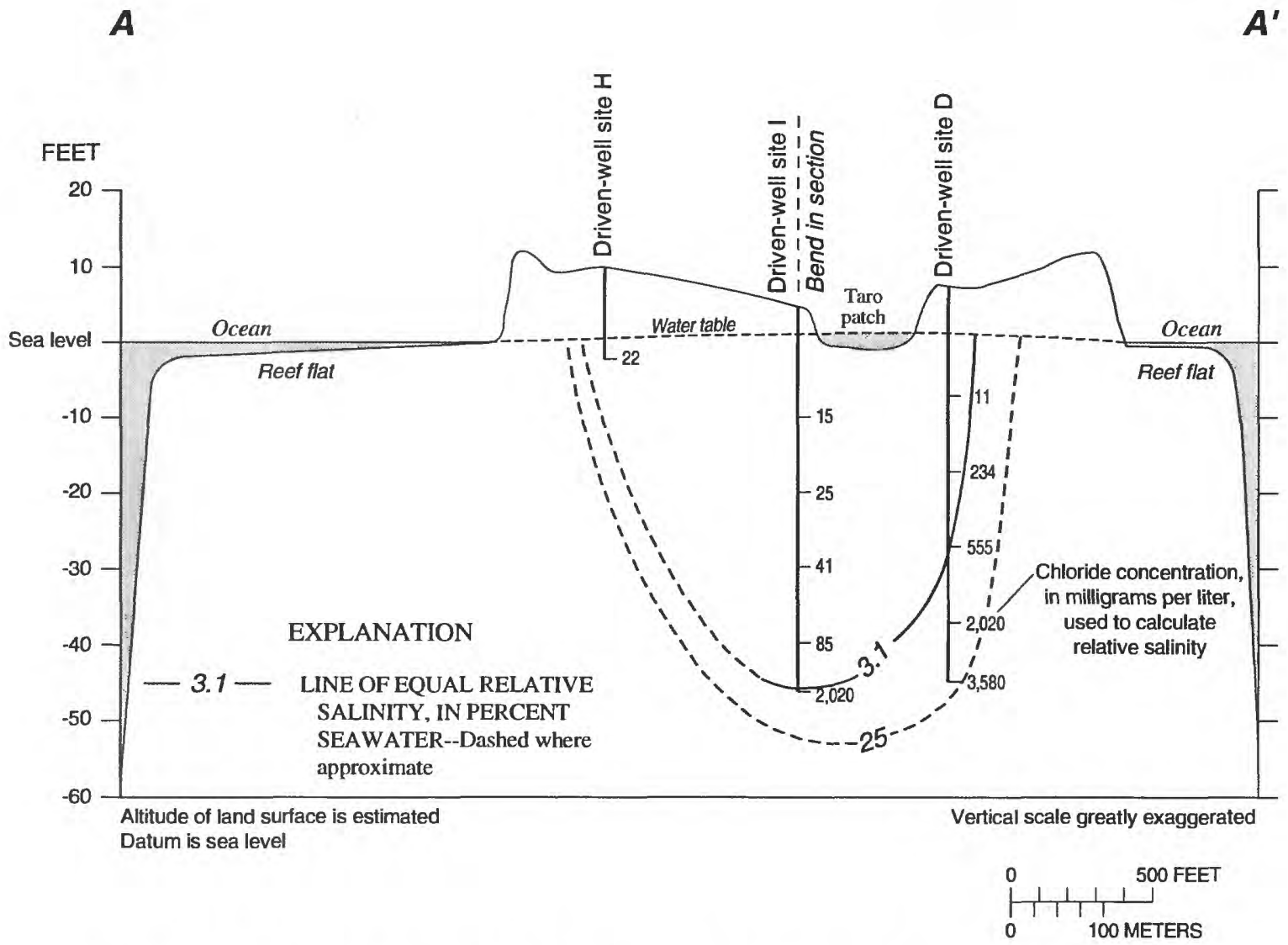

Figure 13. Hydrologic section through the Pingelap freshwater lens, September 1988, Pingelap Island, Pingelap Atoll. Line of section is shown in figure 3.

shows little or no variation in potable thickness as defined by 3.1-percent relative salinity, except for the E-site. Freshwater thickness is calculated by subtracting the depth to water, usually about 5 to $10 \mathrm{ft}$ below land surface, from the depth corresponding to 3.1-percent relative salinity. The September 1988 and August 1989 sampling periods were preceded by monthly rainfall totals of greater than 10 in.; however, the March 29-30, 1990 sampling period was preceded by 3.29 in. in February and 4.95 in. in March (fig. 18). The E-site is the only driven-well cluster that shows a decrease in freshwater thickness $(8 \mathrm{ft}$ ) between August 1989 and March 1990 (fig. 17).

Mean monthly rainfall at Pingelap is consistently greater than 10 in. except for the months of November through March. February is the only month in which rainfall falls below 8 in. (fig. 9). Numerical computer simulations have shown that atoll island freshwater lenses respond quickly to increased rainfall, but are less responsive to decreased rainfall (Underwood, 1990). Therefore, several months of little or no rainfall would be required to show a reduction in the thickness of freshwater under natural conditions. Because this did not occur during the 19-month study period, it was not possible to determine the response of the freshwater lens to climatic stress such as drought.

\section{Quality}

Analyses for temperature, $\mathrm{pH}$, total alkalinity, calcium, magnesium, strontium, sodium, potassium, chloride, sulfate, nitrate, and phosphate were made to determine the chemical characteristics of the water in the freshwater lens at Pingelap Island. Samples were collected from selected dug and driven wells (table 4). For this report, the basic criterion for determining potability is the chloride concentration of the water. The WHO (1971) reports maximum desirable and permissi- 

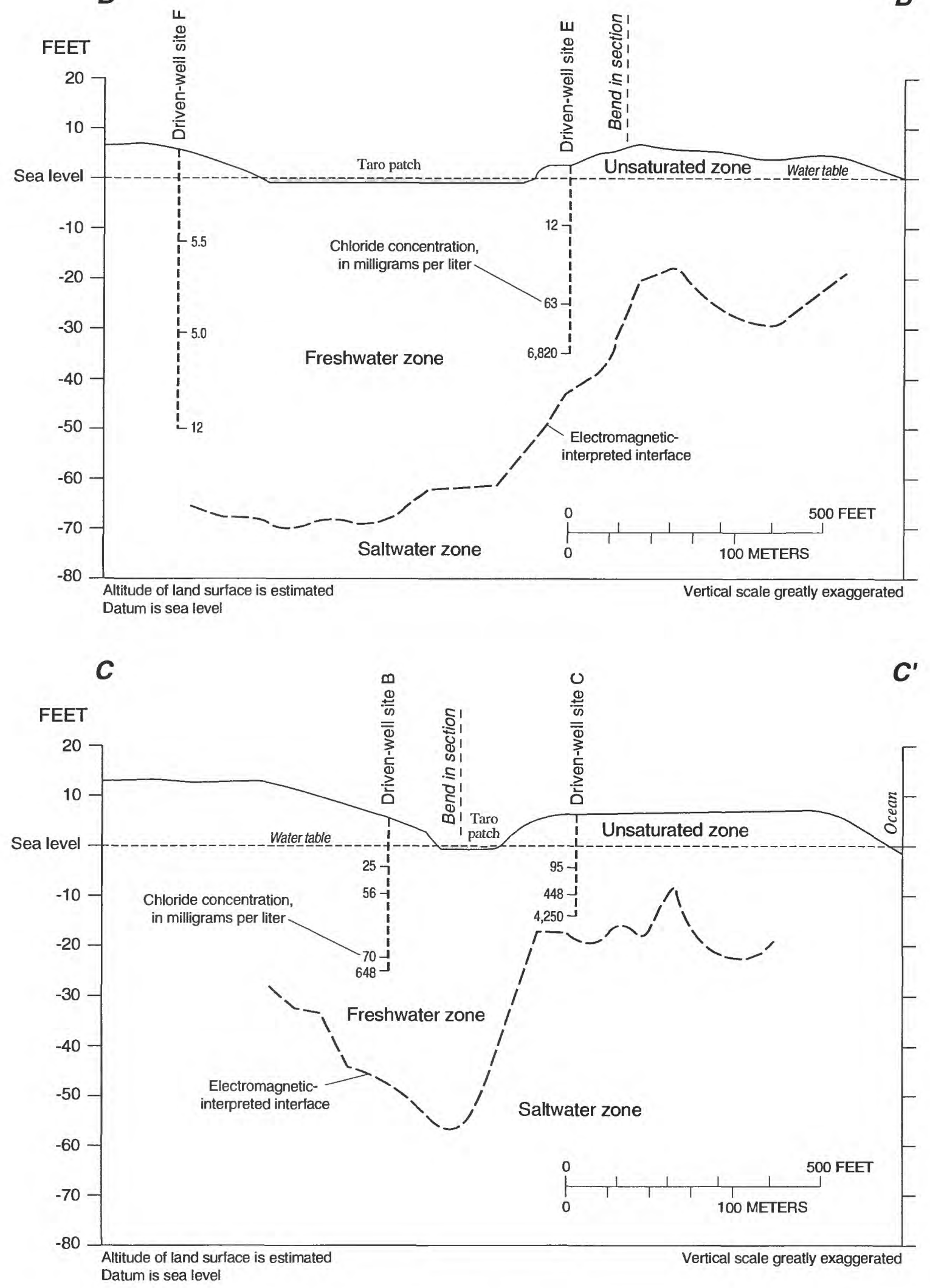

Figure 14. Hydrologic and geophysical sections through the Pingelap freshwater lens, August 1989, Pingelap Island, Pingelap Atoll. Lines of section shown in figure 15. 


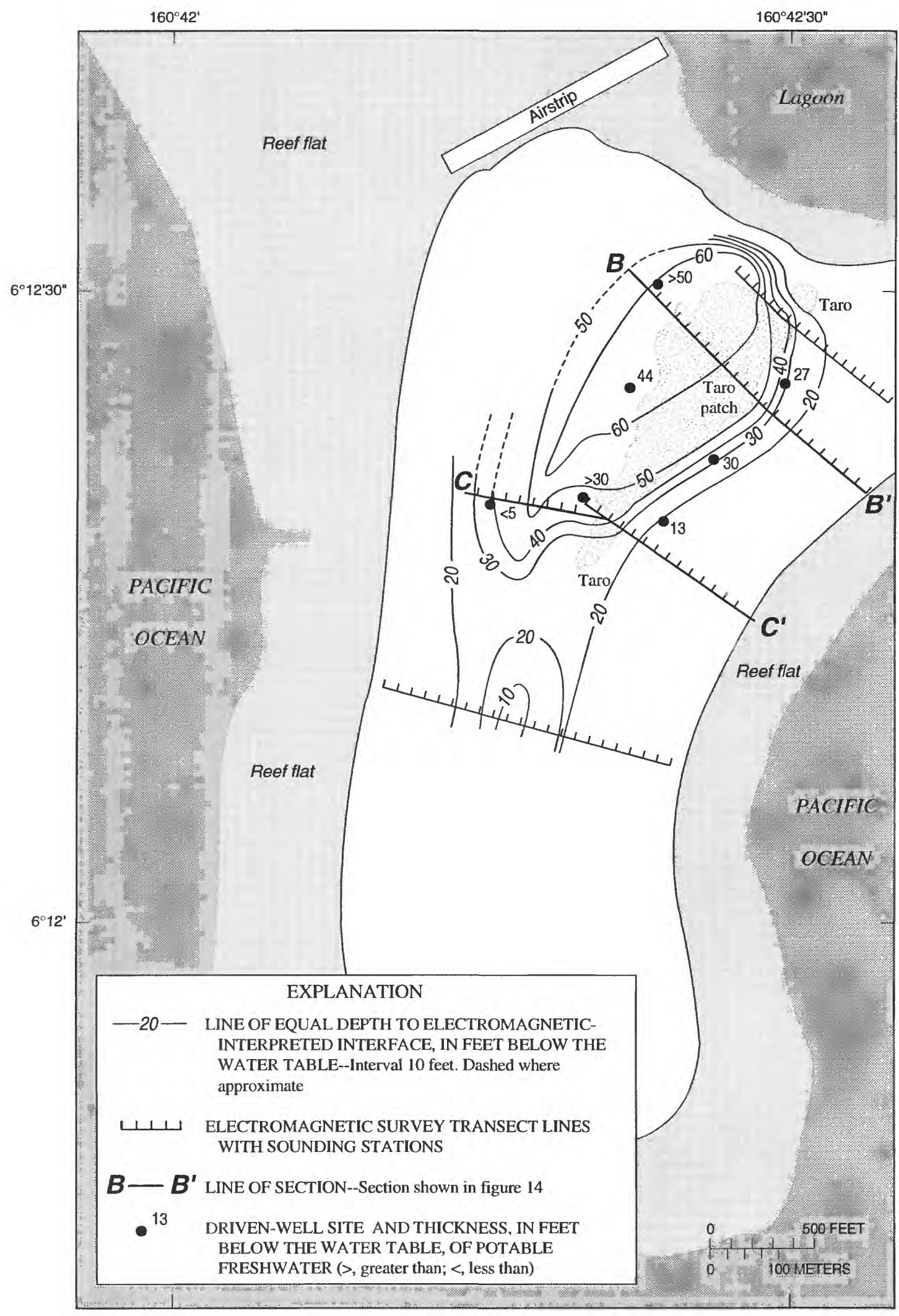

Figure 15. Estimated depth to electromagnetic-interpreted interface and thickness of potable freshwater, Pingelap Island, Pingelap Atoll. 


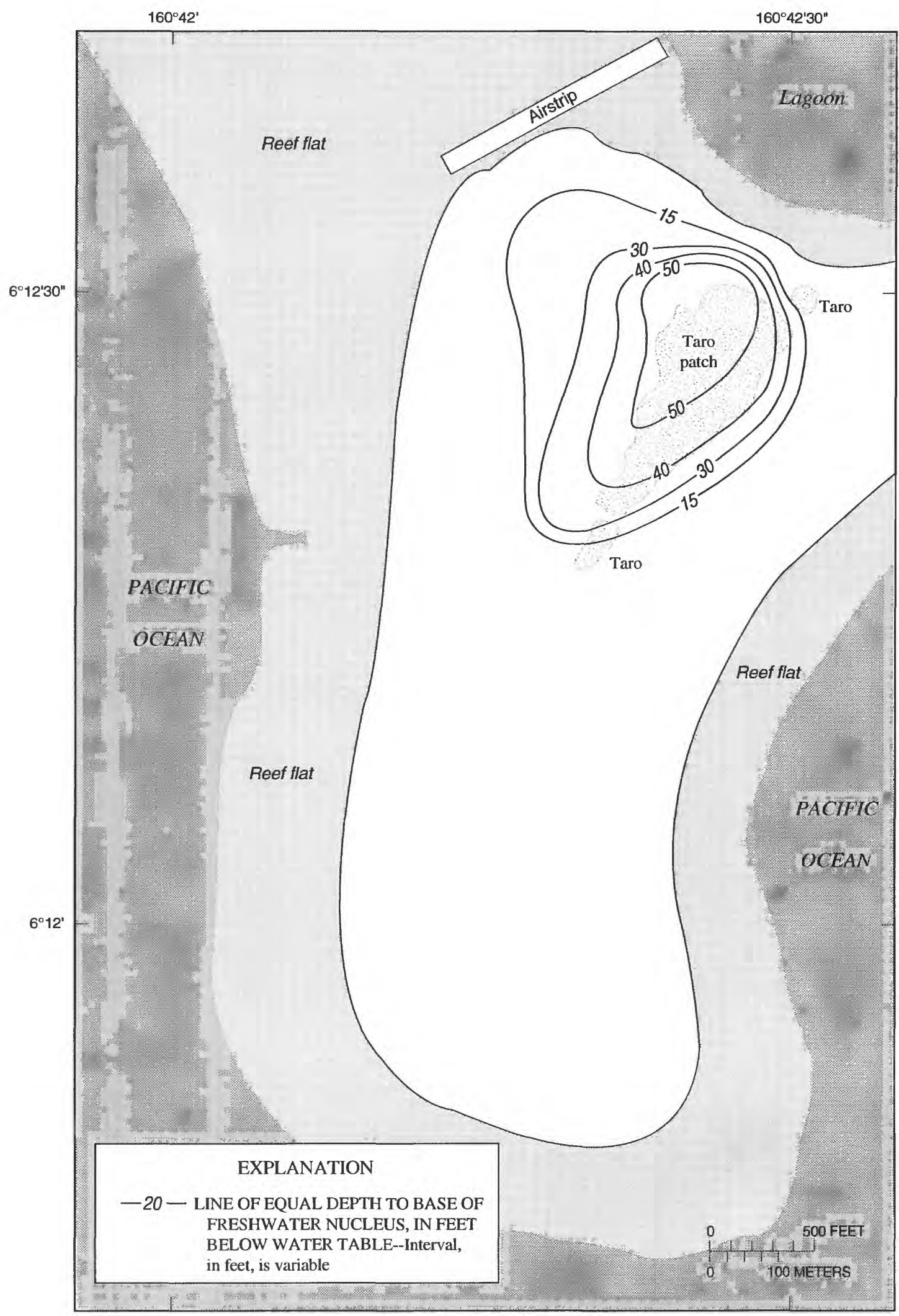

Figure 16. Estimated depth to the base of the freshwater nucleus, Pingelap Island, Pingelap Atoll. 

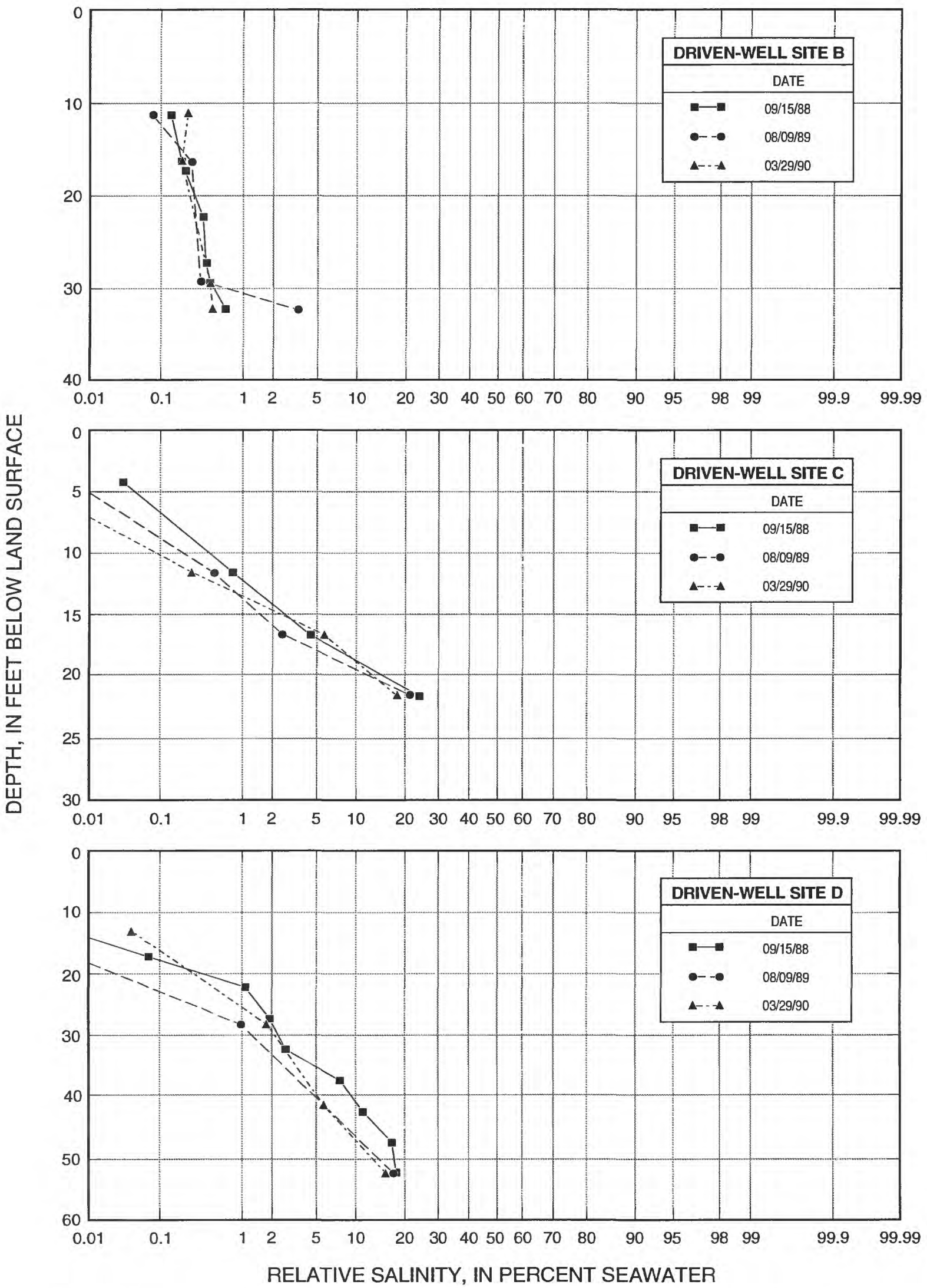

Figure 17. Variation in relative salinity with depth for selected driven-well sites, Pingelap Island, Pingelap Atoll. 

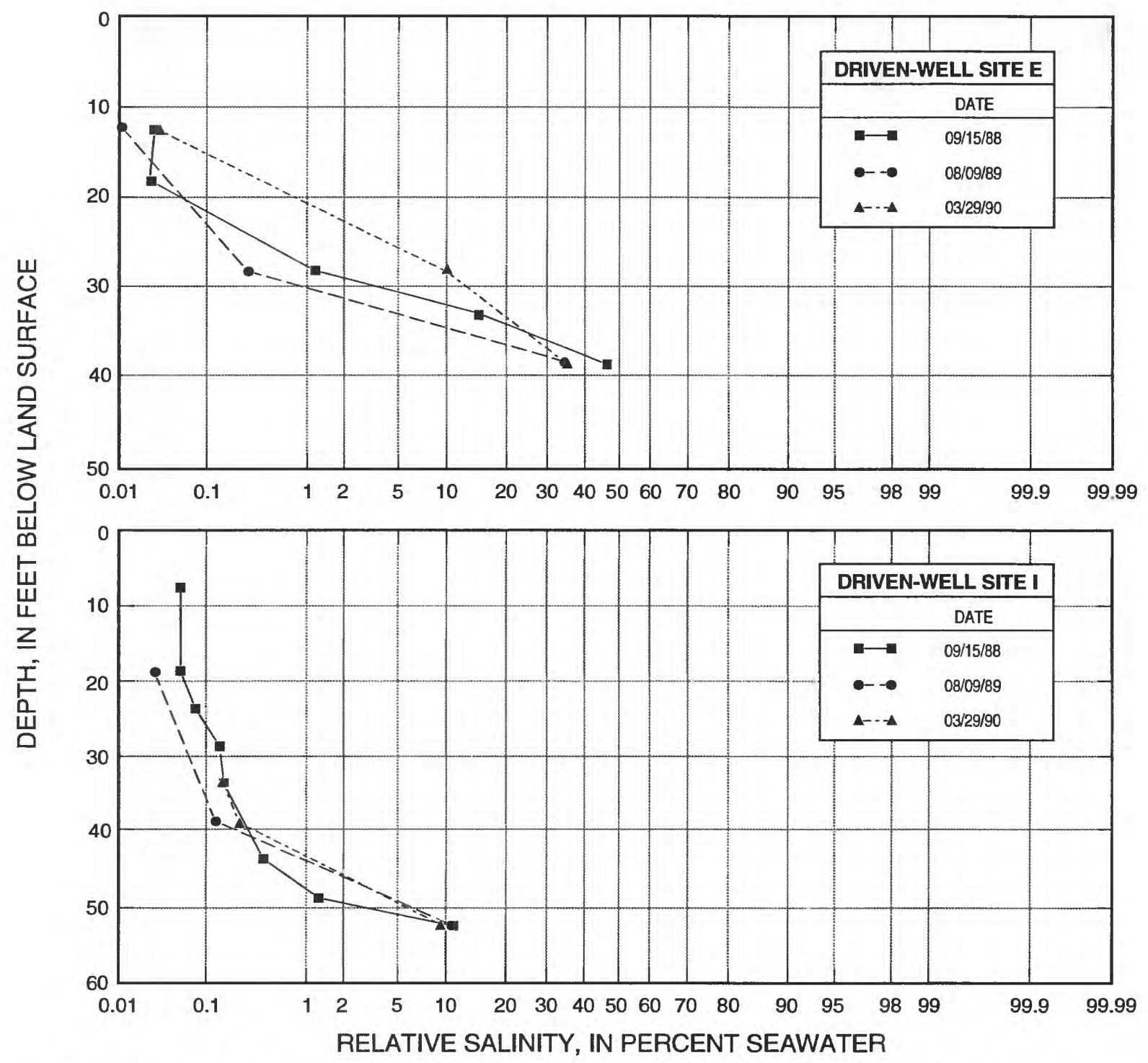

Figure 17. Variation in relative salinity with depth for selected driven-well sites, Pingelap Island, Pingelap Atoll--Continued.

ble levels for chloride of 200 and $600 \mathrm{mg} / \mathrm{L}$, respectively. The lower figure represents the concentration where chloride begins to adversely affect the taste of water.

Another chemical factor to be considered is the hardness of water. Hardness of fresh ground water at Pingelap is attributed to calcium and magnesium, and to a lesser extent strontium. Hard water requires considerable amounts of soap to produce a foam or lather and can also contribute to incrustation that can develop during pumping, when water undergoes changes in temperature and pressure. All water from shallow wells surveyed had hardness values exceeding the WHO (1971) highest desirable level of $100 \mathrm{mg} / \mathrm{L}$ as calcium carbonate $\left(\mathrm{CaCO}_{3}\right)$, but below the maximum permissi- ble level of $500 \mathrm{mg} / \mathrm{L}$ as $\mathrm{CaCO}_{3}$. The hardness in water from shallow wells ranged from 220 to $450 \mathrm{mg} / \mathrm{L}$ as $\mathrm{CaCO}_{3}$. The WHO (1971) levels for hardness are recommended to avoid excessive scale formation in waterdelivery systems.

One of the most common contaminants in ground water is dissolved nitrogen in the form of nitrate. Excessive concentrations of nitrate in drinking water can cause methemoglobinemia in infants. The WHO (1971) level for nitrate in drinking water is $45 \mathrm{mg} / \mathrm{L}$. Unlike most elements in ground water, nitrate is not derived from aquifer materials. Instead, nitrate enters the ground from nitrogen fixing plants, decomposing plant debris, animal and human waste, and fertilizers. Natural 


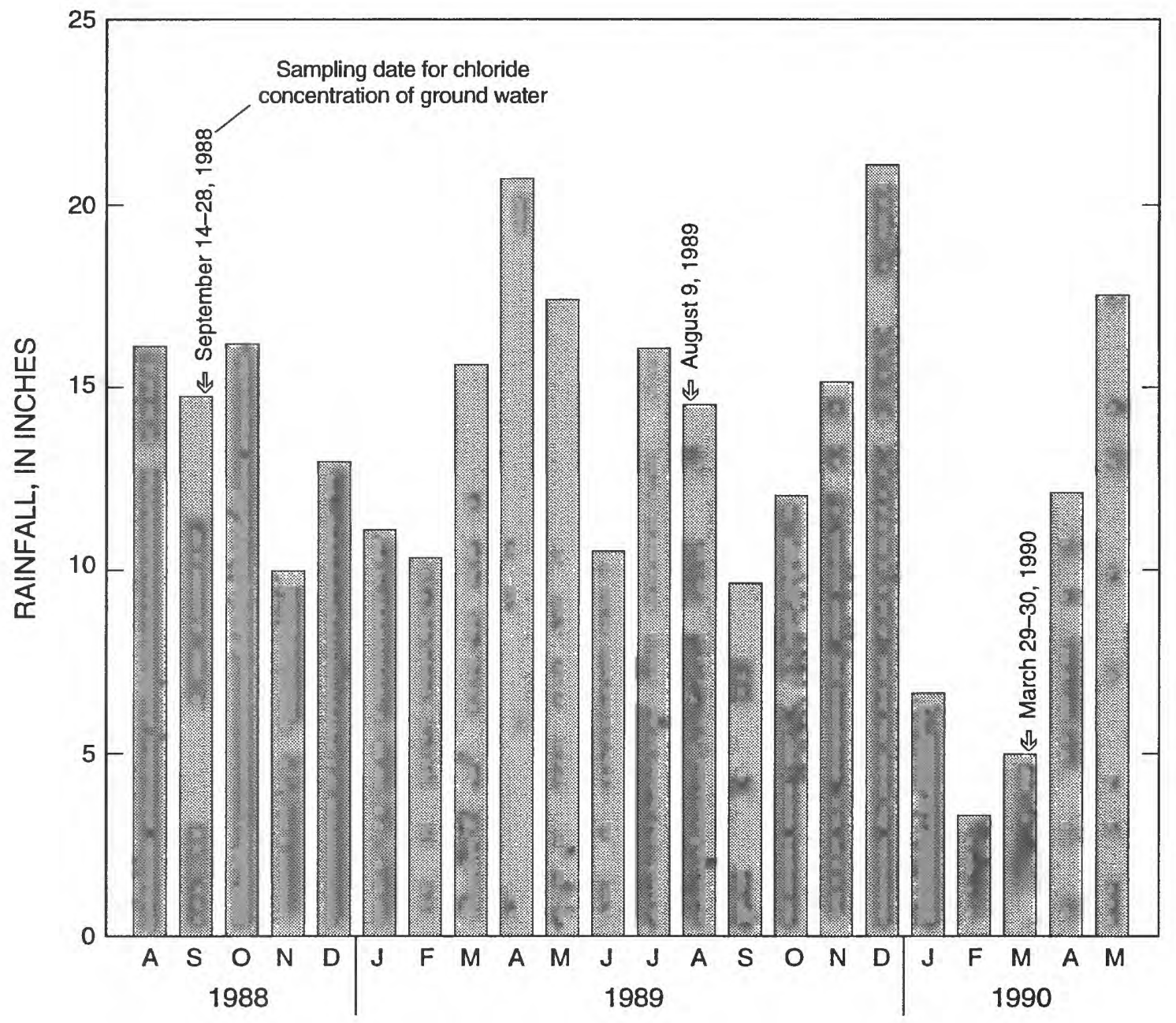

Figure 18. Monthly rainfall totals for August 1988 through May 1990, Pingelap Island, Pingelap Atoll.

nitrate concentration in ground water ranges from 0.1 to $10 \mathrm{mg} / \mathrm{L}$ (Davis and DeWiest, 1966). Because nitrate cannot be removed from water by boiling, the water must be treated by demineralization or distillation.

Nitrate concentrations in water from dug wells at Pingelap are all less than the WHO (1971) level for nitrate in drinking water, except for dug well 2 with a concentration of about $530 \mathrm{mg} / \mathrm{L}$ (table 4 ). The elevated concentration in dug well 2 is probably the result of this well water being used nearby to wash clothes and to clean livestock pens. Before the well water was sampled, a large number of children were playing in and around this open dug well.

Some water-seal toilets on Pingelap have been constructed within $50 \mathrm{ft}$ of an existing dug well. Water- seal toilets discharge water and waste into an unlined pit located directly beneath the toilet. Because ground water flows radially outward from the interior of the island to the sea, livestock and toilets located inland of dug wells may contaminate well water. The potential for such contamination can be reduced by locating livestock and toilets on the seaward side of wells. Because the water table is generally shallow, the depth of the toilet-discharge pit also plays a role in reducing potential contamination of ground water. Construction of waterseal toilets with at least 2 or $3 \mathrm{ft}$ of unsaturated sediments beneath the discharge pit could promote some filtration of discharge water before it reaches the groundwater body. 
Table 7. Relation between reduction in recharge and thickness of freshwater lens, Pingelap island, Pingelap Atoll Assumes ground-water recharge is 80 inches per year and water is withdrawn from the 38.6 acres underlain by an average freshwater thickness of greater than 15 feet (fig. 17).

\begin{tabular}{cccc}
\hline $\begin{array}{c}\text { Percent of } \\
\text { recharge reduced }\end{array}$ & $\begin{array}{c}\text { Amount of } \\
\text { recharge reduced } \\
\text { (inches) }\end{array}$ & $\begin{array}{c}\text { Equivalent quantity } \\
\text { of water pumped } \\
\text { (gallons per day) }\end{array}$ & $\begin{array}{c}\text { Freshwater lens } \\
\text { thickness } \\
\text { (feet) }\end{array}$ \\
\hline 0 & 0 & 0 & 50.0 \\
20 & 16 & 45,900 & 44.8 \\
22 & 17.6 & 50,500 & 44.2 \\
40 & 32 & 91,900 & 38.8 \\
60 & 48 & 137,800 & 31.7 \\
80 & 64 & 183,800 & 22.4 \\
\hline
\end{tabular}

\section{Demand}

The demand for water on Pingelap is expected to increase as a result of a desire to construct sanitary facilities such as showers, flush toilets, and laundry facilities. The population of Pingelap is approximately 870 and is projected to be growing at a rate of 3.3 percent per year (State of Pohnpei, Office of Budget, Planning and Statistics, 1990). Assuming a demand of $50 \mathrm{gal} / \mathrm{d}$ per person and a population of 1,000 persons, 50,000 $\mathrm{gal} / \mathrm{d}$ would be required to meet the demand for water.

\section{Sustainable Yield}

Sustainable yield from a lens of freshwater can be defined as the quantity of water that can be withdrawn from that lens on a long-term basis without producing an undesired result (Todd, 1959). The actual short-term yield is variable and depends on several factors, of which periodic droughts may be the most important. The effect of overdraft on the freshwater lens would be degradation of water quality by saltwater intrusion. For example, when the water table is lowered by pumping water from a well penetrating only the upper freshwater part of the aquifer a local rise in saltwater below the well will occur. This form of saltwater intrusion is known as upconing. An on-going monitoring program is needed to detect early signs of saltwater intrusion.

The withdrawal of ground water from the Pingelap lens will reduce natural discharge from the lens to the ocean and in turn reduce the thickness of freshwater. The reduction in the thickness of freshwater can be estimated by using Mather's (1975) method, which assumes that withdrawing ground water from an aquifer is equivalent to reducing vertical recharge. The estimate is based on the Dupuit assumptions where the thickness of freshwater below sea level $(T)$ is proportional to the square root of the rate of uniform vertical recharge per unit area $(R)$. This relation,

$$
T=a \sqrt{R},
$$

where $a$ is the constant of proportionality, can be used to predict changes in the equilibrium position of the base of the freshwater lens with changes in uniform vertical recharge.

Annual recharge to the freshwater lens at Pingelap is estimated to be about 80 in. and produces a lens that extends to a maximum depth of $50 \mathrm{ft}$ below sea level. Application of the Mather (1975) method yields a proportionality constant of 5.6. If the effective recharge is reduced by 20 percent to 64 in. by pumping, then the new equilibrium freshwater thickness is $5.6 \times \sqrt{64}$, or $44.8 \mathrm{ft}$ below mean sea level. The effect of reducing vertical recharge on the thickness of freshwater is shown in table 7. This method assumes that water is withdrawn uniformly from the freshwater lens and that the thickness of freshwater will be reduced by an equal percentage at all locations.

It should be noted that the proportionality constant in equation 2 is dependent on the thickness of freshwater below sea level. Therefore, if ground-water withdrawals were to occur over an area underlain by $15 \mathrm{ft}$ of freshwater, the proportionality constant would be 1.7 . If the effective recharge is reduced by 20 percent to 64 in. by pumping, then the new equilibrium freshwater thickness is $1.7 \times \sqrt{64}$, or $13.6 \mathrm{ft}$ below mean sea level.

The estimated changes in freshwater thickness predicted by the Mather (1975) method are only first-order approximations, because recharge to the aquifer is not steady but results from periodic rainfall. The estimate can be refined by taking into account the amount of storage that must remain within the lens to maintain pumping during periods of drought. 
The estimated demand for water on Pingelap is about 50,000 gal/d. This demand can be met by reducing recharge by approximately 22 percent and the freshwater lens thickness by approximately $5.8 \mathrm{ft}$ (table 7). Experience on Kwajalein and Diego Garcia Atolls indicates that approximately 30 percent of mean annual recharge to the freshwater nucleus can be developed from a freshwater lens on a long-term basis without adversely affecting the resource (C.D. Hunt Jr., USGS, oral commun., 1990). Thirty percent of the mean annual recharge to the part of the lens underlain by at least 15 $\mathrm{ft}$ of potable water (38.6 acres) at Pingelap is equivalent to a long-term average sustainable yield of $69,000 \mathrm{gal} / \mathrm{d}$. It may be possible to increase ground-water pumpage beyond that quantity, provided that the transition zone is continually monitored with a series of driven-well clusters to allow early detection of saltwater intrusion.

Rainfall, and therefore recharge, is variable in time, and may require that well production be adjusted in response to changes in the condition of the lens. The estimate of long-term sustainable yield can be refined by monitoring the response of the freshwater lens to various pumping rates and rainfall. Pumping rates can be increased until water demand is met or saltwater intrusion is detected. Saltwater intrusion, if present, can be alleviated by reducing pumping rates until the chloride concentration of the pumped water decreases to acceptable levels

\section{Development Alternatives}

The ground-water resource of Pingelap Island has been developed in only a limited way, mostly through shallow dug wells from which water is dipped for washing purposes. These open wells are easily contaminated with waste materials and bacteria that can present a safety hazard. Two of the driven wells installed during this study were outfitted with a hand pump and a concrete pad. These wells are inexpensive, sanitary, and available to the community as a whole.

Use of ground water at Pingelap could be increased by installing vertical-tube or horizontal-infiltration wells. In the absence of an electrical power system, these wells could be outfitted with solar, windmill, or gasoline driven pumps. Schematic diagrams of the vertical and horizontal wells are shown in figures 19 and 20 , respectively. Both designs rely on the establishment of sea-level and mean-lower-low-water datum planes for proper location of the well screens.

Placement of production wells over the thickest part of the lens along the western side of the taro patch would aid in minimizing the possibility of saltwater intrusion. Regular spacing of wells would distribute the effects of pumpage evenly and prevent localized overdraft. Experience on Diego Garcia Atoll indicates that a shallow vertical well depth of about $10 \mathrm{ft}$ and individual pumping rates of about $10 \mathrm{gal} / \mathrm{min}$ or less helps to prevent excessive drawdown and saltwater intrusion. Vertical-tube wells are less expensive and easier to construct than horizontal-infiltration wells, but horizontal wells allow pumping at higher rates from a single well without causing excessive drawdown and thus reduce the potential for upconing of saltwater. Horizontal-infiltration wells are similar in construction to the vertical-tube wells. Horizontal wells have a water-tight pump sump into which water can flow only from the horizontal-infiltration pipes (D.A. Davis, USGS, written commun., 1986). Fewer horizontal than vertical wells are needed to provide an equivalent total pumping rate.

Certain land-use activities may contaminate the ground-water resource. Disposal of human and animal waste represents the greatest potential for ground-water contamination at Pingelap. Farming activities also may contribute contaminants to the ground water in the form of fertilizers and pesticides. The separation of water development areas from sources of contamination will aid in the protection of the freshwater resource.

\section{Need for Additional Data}

An understanding of the relation between well production, recharge, and water quality is needed in the management of the ground-water resource at Pingelap. This relation can be developed from rainfall, pumpage, and water-quality data (chloride and nitrate) collected routinely from a network of shallow-water-table wells, deep driven-wells, and production wells. The shallowwater-table wells and deep driven-wells need to be located within and around the perimeter of the anticipated area of ground-water development to determine spatial and temporal changes in water quality, estimate changes in storage, and define responses to variations in recharge and discharge (pumpage). 


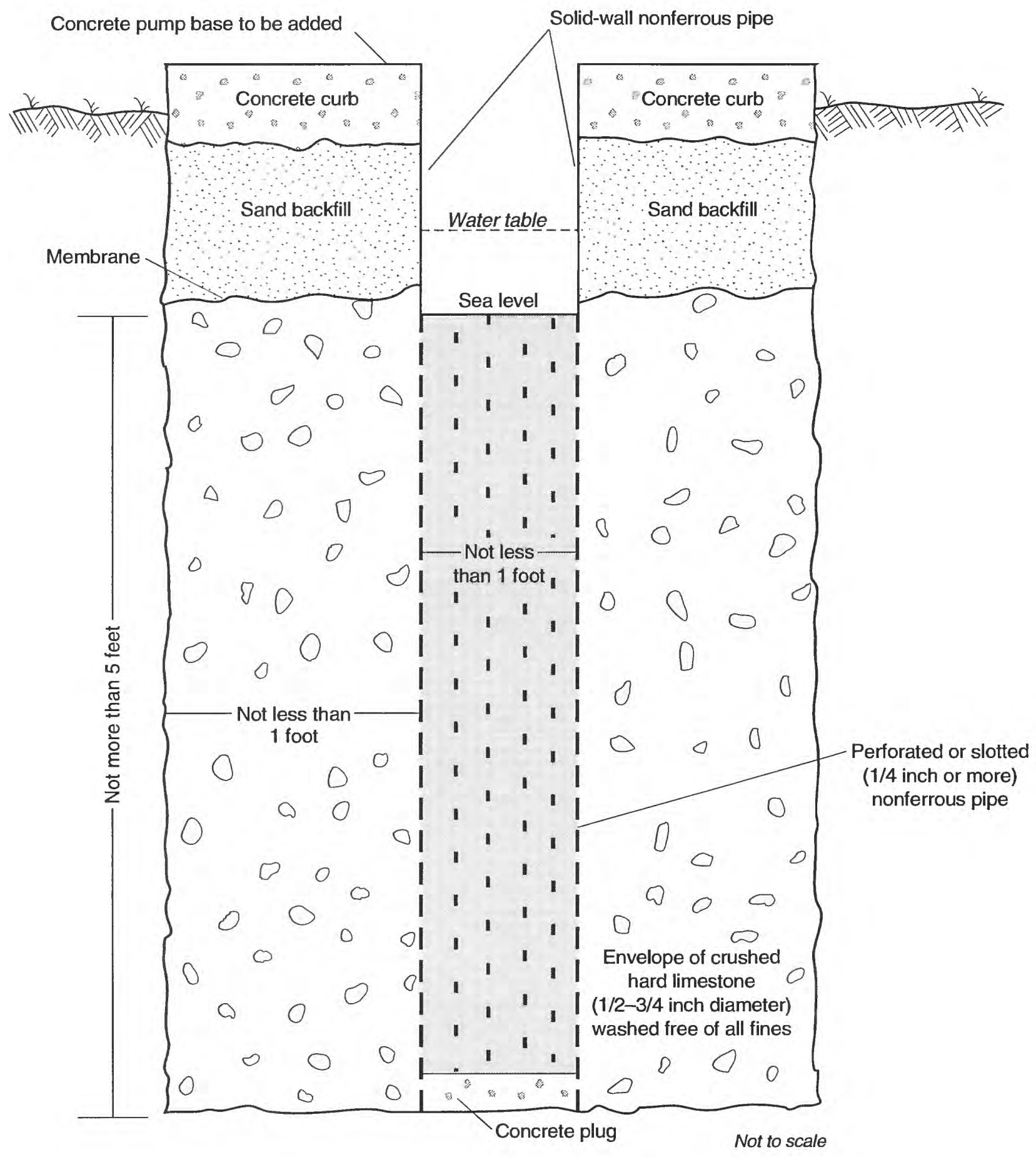

Figure 19. Schematic of vertical-tube well (modified from Hamlin and Anthony, 1987). 


\section{PLAN VIEW}

Not to scale

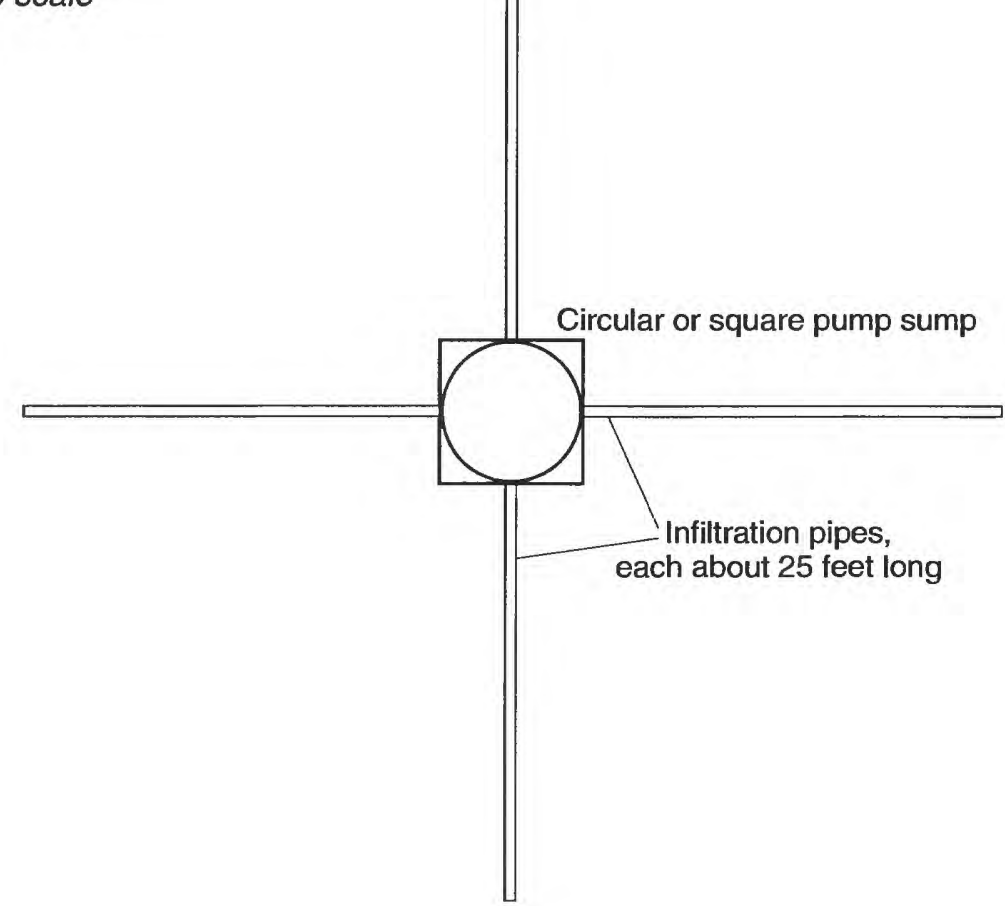

\section{VERTICAL SECTION \\ Not to scale}

Mean-lower low-water datum

Invert of infiltration pipe at 1 foot below mean-lower-low water sea-level datum plane

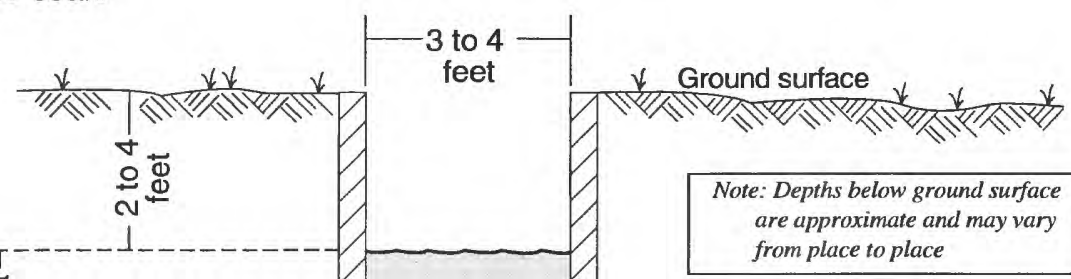

Water-tight, nonferrous Membrane

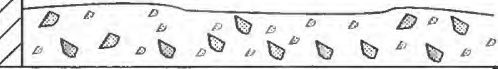

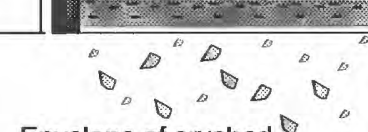
Envelope of crushed hard limestone (1/2-3/4 inch diameter) washed free of all fines

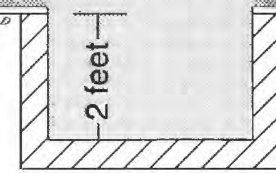

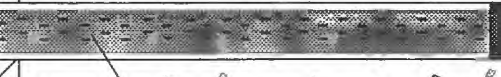

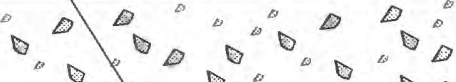
- 8

Perforated or slotted nonferrous infiltration pipe, not less than 1 foot in diameter

Figure 20. Schematic of horizontal-infiltration well (modified from Hamlin and Anthony, 1987). 


\section{SUMMARY}

The demand for water on Pingelap Island, Pingelap Atoll is expected to increase as a result of a desire to construct sanitary facilities such as showers, flush toilets, and laundry facilities. Water supplies on Pingelap are obtained from individual and community rainwatercatchment systems and from shallow dug wells that yield fresh to brackish ground water. During extended dry periods the demand for potable water commonly exceeds the supply. One way to alleviate the chronic water-supply shortage is to further develop groundwater resources.

The fresh ground-water lens at Pingelap is the most favorable alternative source of freshwater in terms of storage and availability. Long-term average daily recharge to the freshwater lens at Pingelap is about 230,000 gallons ( 50 percent of rainfall) on the basis of an average annual rainfall of 160 inches. It is estimated that about 384 million gallons of freshwater are stored in the Pingelap lens and about 69,000 gallons per day could be developed on a sustained basis. The estimated demand for water is about 50,000 gallons per day.

The hydrogeologic framework at Pingelap, to a large extent, controls the shape and size of the freshwater nucleus. A conceptual hydrogeologic model of Pingelap Island was developed from near-surface observations combined with published descriptions of the hydrogeology of other atoll islands in the western Pacific. This model incorporates a dual-aquifer system consisting of surficial Holocene deposits overlying more permeable Pleistocene deposits. Layering and lateral gradation of back-reef and marginal-lagoon deposits affect the occurrence and flow of freshwater within the Holocene deposits. The hydraulics of the system are characterized by long-term, mainly horizontal flow that is driven by recharge, and short-term vertical fluctuations that are driven by semi-diurnal tides. Tidal fluctuations expand the transition zone, which ultimately reduces storage in the freshwater lens.

The extent of the potable part of the freshwater lens at Pingelap is delineated by the $600 \mathrm{mg} / \mathrm{L}$ chlorideconcentration contour. The depth of the chlorideconcentration contour was interpolated from relative salinity-depth profiles on the basis of chloride-concentration data from driven-well clusters. Profiles of relative salinity correlate fairly well with geophysical profiles of the lens. The volume of the freshwater nucleus was approximated by combining chloride-concen- tration and geophysical data to produce a plan-view map of the thickness of potable freshwater. Results of chemical analyses show that water from the Pingelap freshwater lens is within the WHO (1971) recommended maximum permissible drinking-water limits. Elevated nitrate concentrations in some locations, however, may indicate potentially harmful bacterial contamination.

The ground-water resource at Pingelap can be developed using either a network of vertical-tube wells or horizontal-infiltration wells. Network management would entail monitoring rainfall, pumpage, and water quality in shallow water-table wells, deep driven-wells, and production wells. Monitoring water quality will identify chloride-concentration increases that indicate saltwater intrusion. Well production can be adjusted in response to changes in the chloride-concentration of the freshwater lens. Records of individual well and total well-field pumping rates will permit evaluation of sustainable yield under actual development conditions.

The ground-water resource on Pingelap Island, Pingelap Atoll, can be used in conjunction with individual rainwater-catchment systems: rainwater can be used for drinking and cooking and ground water can be used for sanitary uses. When rainwater-catchment systems fail during extended dry periods, ground water would be available to meet the total demand.

\section{REFERENCES CITED}

Anthony, S.S., 1992, Electromagnetic methods for mapping freshwater lenses on Micronesian atoll islands: Journal of Hydrology, v. 137, p. 99-111.

----, 1996a, Hydrogeology and ground-water resources of Kahlap Island, Mwoakilloa Atoll, State of Pohnpei, Federated States of Micronesia: U.S. Geological Survey Water Resources Investigations Report 91-4184, 44 p.

----, 1996b, Hydrogeology and ground-water resources of Ngatik Island, Sapwuahfik Atoll, State of Pohnpei, Federated States of Micronesia: U.S. Geological Survey Water Resources Investigations Report 93-4117, 44 p.

Anthony, S.S., Peterson, F.L., Mackenzie, F.T., and Hamlin, S.N., 1989, Geohydrology of the Laura fresh-water lens, Majuro Atoll: A hydrogeochemical approach: Geological Society of America Bulletin, v. 101, p. 1066-1075.

Ayers, J.F., and Vacher, H.L., 1986, Hydrogeology of an atoll island: A conceptual model from detailed study of a Micronesian example: Ground Water, v. 24, p. 185-198. 
Buddemeier, R.W., and Holladay, Gale, 1977, Atoll hydrolo$\mathrm{gy}$, island groundwater characteristics and their relationship to diagenesis: Proceedings of the $3 \mathrm{~d}$ Interconference Coral Reef Symposium, Miami, Fla., p. 167-173.

Cox, D.C., 1951, The hydrology of Arno Atoll, Marshall Islands: Scientific Investigations in Micronesia, Pacific Science Board [Hawaii], National Research Council, $29 \mathrm{p}$.

Davis, S.N., and DeWiest, R.J.M., 1966, Hydrogeology: New York, Wiley, $463 \mathrm{p}$.

Emery, K.D., Tracey, J.I., Jr., and Ladd, H.S., 1954, Geology of Bikini and nearby atolls: U.S. Geological Survey Professional Paper 260-A, 265 p.

Freeze, R.A., and Cherry, J.A., 1979, Groundwater. Englewood Cliffs, N. J., Prentice-Hall, 604 p.

Griggs, J., 1989, Numerical simulation of groundwater development schemes for the Laura area of Majuro Atoll, Marshall Islands: Ph. D. dissertation, University of Hawaii at Manoa, Hawaii, 203 p.

Hamlin, S.N., and Anthony, S.S., 1987, Ground-water resources of the Laura area, Majuro Atoll, Marshall Islands: U.S. Geological Survey Water- Resources Investigations Report 87-4047, 69 p.

Herman, M.E., Buddemeier, R.W., and Wheatcraft, S.W., 1986, A layered aquifer model of atoll island hydrology: A validation of a computer simulation: Journal of Hydrology, v. 84, p. 303-322.

Hogan, P., 1988, Modeling of freshwater-seawater interaction on Enjebi Island, Enewetak Atoll: M. S. thesis, San Jose State University, Calif., 141 p.

Hunt, C.D., Jr., and Peterson, F.L., 1980, Ground-water resources of Kwajalein Island, Marshall Islands: University of Hawaii, Water Resources Research Center, Technical Report 126, $91 \mathrm{p}$.

Hvorslev, M.J., 1951, Time lag and soil permeability in groundwater observations: U.S. Army Corps of Engineers Waterways Experiment Station Bulletin 36, Vicksburg, Miss.

Interpex Limited, 1988, EMIX 34 user's manual: Golden, Colo., 89 p.

Kauahikaua, J., 1987, Description of a freshwater lens at Laura Island, Majuro Atoll, Republic of the Marshall Islands, using electromagnetic profiling: U.S. Geological Survey Open-File Report 87-582, 32 p.

Ladd, H.S., and Schlanger, S.O., 1960, Drilling operations on Enewetak Atoll: U.S. Geological Survey Professional Paper 260-Y, p. 863-903.

Ladd, H.S., Tracey, J.I., Jr., and Gross, M.G., 1970, Deep drilling on Midway Atoll: U.S. Geological Survey Professional Paper 680-A, p. A1-A22.

Lalou, C., Labeyrie, J., and Delibrias, G., 1966, Datation des calcaires coralliens de l'atoll de Mururoa (archipel des Tuamotu) de l'epoque actuelle jusqu'a 5,000 ans.: Comptes Rendus Acad. Sci. 263-D, p. 1946-1949.
Marshall, J.F., and Jacobson, G., 1985, Holocene growth of a mid-Pacific atoll: Tarawa, Kiribati: Coral Reefs, v. 4, p. 11-17.

Mather, J.D., 1975, Development of the groundwater resources of small limestone islands: Quarterly Journal of Engineering Geology, v. 8, p. 141-150.

McNeill, J.D., 1980a, Electromagnetic terrain conductivity measurement at low induction numbers: Geonics Ltd. Technical Note-6, Mississauga, Ontario, 15 p.

Nullet, D., 1987, Water balance of Pacific atolls: Water Resources Bulletin, v. 23, p. 1125-1132.

Schlanger, S.O., 1963, Subsurface geology of Enewetak Atoll: U.S. Geological Survey Professional Paper 260-B, p. 991-1066.

Selley, R.C., 1970, Ancient sedimentary environments - A brief survey: Ithaca, N. Y., Cornell University Press, $237 \mathrm{p}$.

State of Pohnpei, Office of Budget, Planning and Statistics, 1990, Pohnpei State Government, Pohnpei State statistics yearbook-1989: Federated States of Micronesia, $152 \mathrm{p}$.

Stewart, M.T., 1982, Evaluation of electromagnetic methods for rapid mapping of salt-water interfaces in coastal aquifers: Ground Water, v. 20, p. 538-545.

----, 1988, Electromagnetic mapping of fresh-water lenses on small oceanic islands: Ground Water, v. 26, p. 187 191.

Takasaki, K.J., 1989, Ground-water resources of selected high volcanic islands of Truk with emphasis on small village supplies: U.S. Geological Survey Water-Resources Investigations Report 88-4163, 60 p.

Taylor, R.C., 1973, An atlas of Pacific Islands rainfall: University of Hawaii, Hawaii Institute of Geophysics, Data Report 25, 5 p.

Todd, D.K., 1959, Ground-water hydrology: New York, Wiley, $336 \mathrm{p}$.

Tracey, J.I., and Ladd, H.S., 1974, Quarternary history of Enewetak and Bikini Atolls, Marshall Islands: Proceedings of the Second International Coral Reef Symposium, December 1974, Brisbane, Australia, p. 537-550.

Underwood, M.R., 1990, Atoll island hydrogeology: Conceptual and numerical models: Ph. D. dissertation, University of Hawaii at Manoa, Hawaii, 205 p.

Vacher, H.L., 1974, Groundwater hydrology of Bermuda: Hamilton, Bermuda, Government of Bermuda Public Works Department, 87 p.

van der Brug, Otto, 1986, The 1983 drought in the western Pacific: U.S. Geological Survey Open-File Report 85418, 89 p.

World Health Organization, 1971, International standards for drinking water: (2d ed.): Geneva, Switzerland, 72 p. 
Table 2. Temperature, specific conductance, and chloride-concentration data from dug wells, Pingelap Island, Pingelap Atoll

Well no: DW is dug well and number is well designation.

$\left[{ }^{\circ} \mathrm{C}\right.$, degrees Celsius; $\mu \mathrm{S} / \mathrm{cm}$, microsiemens per centimeter at $25^{\circ} \mathrm{C}$; $\mathrm{mg} / \mathrm{L}$, milligrams per liter; --, no data.]

\begin{tabular}{|c|c|c|c|c|c|c|}
\hline Well no. & Date & Time & $\begin{array}{c}\text { Temperature } \\
\left({ }^{\circ} \mathrm{C}\right)\end{array}$ & $\begin{array}{c}\text { Specific } \\
\text { conductance } \\
(\mu \mathrm{S} / \mathrm{cm})\end{array}$ & $\begin{array}{l}\text { Chloride } \\
\text { concentration } \\
\text { (mg/L) }\end{array}$ & Owner \\
\hline \multirow[t]{5}{*}{ DW-1 } & $12-15-86$ & 0840 & 27.0 & 1,225 & 140 & Osiro Samson \\
\hline & $12-16-86$ & 1600 & 27.0 & 1,536 & - & \\
\hline & $09-27-88$ & 0845 & 26.2 & 1,970 & 298 & \\
\hline & $08-09-89$ & 1030 & - & 2,130 & 500 & \\
\hline & $03-30-90$ & 1420 & 28.5 & 8,100 & 2,230 & \\
\hline \multirow[t]{5}{*}{ DW-2 } & $12-15-86$ & 0850 & 26.5 & 350 & 10 & Iras Boaz \\
\hline & $12-16-86$ & 1500 & 27.0 & 430 & 9.5 & \\
\hline & $09-27-88$ & 0840 & 25.8 & 316 & 12.3 & \\
\hline & 08-09-89 & 1045 & -- & 425 & 10 & \\
\hline & $03-30-90$ & 1440 & 28.5 & 1,280 & 152 & \\
\hline \multirow[t]{3}{*}{ DW-3 } & $12-15-86$ & 0900 & 26.0 & 205 & 10 & Kiaos Alexander \\
\hline & $09-27-88$ & 0855 & 25.8 & 330 & 7.4 & \\
\hline & 08-09-89 & 1050 & -- & 305 & 10.9 & \\
\hline \multirow[t]{4}{*}{ DW-4 } & $12-15-86$ & 0900 & 26.5 & 590 & 23 & Ilander Charley \\
\hline & $09-27-88$ & 0940 & 26.6 & 759 & 44.5 & \\
\hline & 08-09-89 & 1055 & -- & 743 & 35 & \\
\hline & $03-30-90$ & 1450 & 27.0 & 840 & 36.5 & \\
\hline \multirow[t]{4}{*}{ DW-5 } & $12-15-86$ & 0910 & 26.0 & 150 & 8 & Kapwuhs James \\
\hline & $09-27-88$ & 0910 & 25.4 & 101 & 2.9 & \\
\hline & 08-09-89 & 1100 & - & 196 & 5.2 & \\
\hline & $03-30-90$ & 1500 & 28.0 & 620 & 8.4 & \\
\hline \multirow[t]{4}{*}{ DW-6 } & $12-15-86$ & 0915 & 26.0 & 380 & 8 & Rose Samual \\
\hline & $09-27-88$ & 0920 & 26.4 & 649 & 21 & \\
\hline & 08-09-89 & 1120 & -- & 516 & 9.4 & \\
\hline & $03-30-90$ & 1000 & 27.5 & 880 & 37.7 & \\
\hline \multirow[t]{4}{*}{ DW-7 } & $12-15-86$ & 0925 & 27.2 & 500 & 20 & Ionadas Delensa \\
\hline & $09-27-88$ & 0950 & 26.5 & 972 & 48 & \\
\hline & 08-09-89 & 1125 & -- & 562 & 34 & \\
\hline & $03-30-90$ & 1130 & 28.0 & 1,180 & 83.4 & \\
\hline \multirow[t]{3}{*}{ DW-8 } & $09-27-88$ & 0925 & 26.0 & 461 & 14.6 & Iksale Charley \\
\hline & 08-09-89 & 1120 & -- & 360 & 16.8 & \\
\hline & $03-30-90$ & 1115 & 28.0 & 600 & 18.6 & \\
\hline \multirow[t]{5}{*}{ DW-9 } & $12-15-86$ & 0945 & 26.0 & 150 & 20 & Samenson Willy \\
\hline & $12-16-86$ & & 27.0 & 190 & -- & \\
\hline & $09-27-88$ & 1015 & 25.0 & 97 & 2.4 & \\
\hline & 08-09-89 & 0835 & -- & 152 & 6 & \\
\hline & $03-30-90$ & 0850 & 27.5 & 590 & 4.9 & \\
\hline \multirow[t]{4}{*}{ DW-10 } & $12-15-86$ & 0950 & 28.0 & 590 & 20 & Sidos Isaac \\
\hline & $09-27-88$ & 1020 & 27.5 & 546 & 10 & \\
\hline & 08-09-89 & 0830 & -- & 414 & 6.4 & \\
\hline & $03-30-90$ & 0840 & 27.5 & 670 & 16.8 & \\
\hline
\end{tabular}


Table 2. Temperature, specific conductance, and chloride-concentration data from dug wells, Pingelap Island, Pingelap Atoll--Continued

\begin{tabular}{|c|c|c|c|c|c|c|}
\hline Well no. & Date & Time & $\begin{array}{c}\text { Temperature } \\
\left({ }^{\circ} \mathrm{C}\right)\end{array}$ & $\begin{array}{c}\text { Specific } \\
\text { conductance } \\
(\mu \mathrm{S} / \mathrm{cm})\end{array}$ & $\begin{array}{l}\text { Chloride } \\
\text { concentration } \\
\text { (mg/lL) }\end{array}$ & Owner \\
\hline \multirow[t]{5}{*}{ DW-11 } & $12-15-86$ & 1000 & 27.0 & 140 & 10 & Ensiner Risana \\
\hline & $12-16-86$ & 1640 & 26.5 & 200 & 8.9 & \\
\hline & $09-27-88$ & 1005 & 25.0 & 98 & 3.1 & \\
\hline & 08-09-89 & 0850 & -- & 160 & 9.7 & \\
\hline & $03-30-90$ & 0930 & 27.0 & 660 & 29.4 & \\
\hline \multirow[t]{3}{*}{ DW-12 } & $12-15-86$ & 1005 & 28.0 & 295 & 20 & Aldis Clark \\
\hline & $09-27-88$ & 0955 & 26.2 & 325 & 10.6 & \\
\hline & 08-09-89 & 0900 & -- & 396 & 12 & \\
\hline \multirow[t]{4}{*}{ DW-13 } & $12-16-86$ & 1550 & 27.0 & 500 & 8.9 & Iksale Charley \\
\hline & $09-28-88$ & 1105 & 27.2 & 483 & 15.4 & \\
\hline & 08-09-89 & 1010 & - & 549 & 10.8 & \\
\hline & $03-30-90$ & 1240 & 29.5 & 730 & 7.7 & \\
\hline \multirow[t]{3}{*}{ DW-14 } & $12-16-86$ & 1630 & 27.0 & 595 & -- & Kehpa William \\
\hline & 08-09-89 & 0845 & -- & 372 & 9.8 & \\
\hline & $03-30-90$ & 0910 & 27.0 & 700 & & \\
\hline \multirow[t]{2}{*}{ DW-15 } & $12-16-86$ & 1630 & 27.0 & 865 & - & Sochy Soaz \\
\hline & $03-30-90$ & 0920 & 27.0 & 740 & 34.4 & \\
\hline \multirow[t]{5}{*}{ DW-16 } & $12-15-86$ & 0935 & 27.0 & 400 & 16 & Ampe Entere \\
\hline & $12-16-86$ & 1620 & 27.2 & 460 & 14 & \\
\hline & $09-27-88$ & 1010 & 26.8 & 670 & 44.6 & \\
\hline & 08-09-89 & 0840 & - & 274 & 4.9 & \\
\hline & $03-30-90$ & 0900 & 26.5 & 620 & 5.7 & \\
\hline \multirow[t]{3}{*}{ DW-17 } & $09-28-88$ & 1030 & 25.9 & 192 & 4.8 & David Pony \\
\hline & 08-09-89 & 0930 & - & 273 & 14.8 & \\
\hline & $03-30-90$ & 1205 & 27.5 & 825 & 20.8 & \\
\hline \multirow[t]{4}{*}{ DW-18 } & $12-17-86$ & -- & -- & -- & 26 & Danny Leopold \\
\hline & $09-28-88$ & 1125 & -- & -- & 705. & \\
\hline & 08-09-89 & 1025 & - & 153 & 4.4 & \\
\hline & 03-31-90 & 1030 & - & -- & 1,330 & \\
\hline \multirow[t]{3}{*}{ DW-19 } & $09-28-88$ & 1025 & 27.3 & 656 & 36.3 & Iprian Caplle \\
\hline & 08-09-89 & 0925 & -- & 731 & 49 & \\
\hline & $03-30-90$ & 1200 & 28.0 & 1,200 & 85 & \\
\hline \multirow[t]{3}{*}{ DW-20 } & $09-28-88$ & 1045 & 26.5 & 425 & 21 & Lanso Lanso \\
\hline & 08-09-89 & 0935 & -- & 474 & 16 & \\
\hline & 03-30-90 & 1220 & 27.5 & 825 & 27 & \\
\hline DW-21 & 03-30-90 & 0945 & 27.0 & 860 & 39.6 & Eser Andon \\
\hline
\end{tabular}


Table 3. Temperature, specific conductance, and chloride-concentration data from driven wells, Pingelap Island, Pingelap Atoll $\left[{ }^{\circ} \mathrm{C}\right.$, degrees Celsius; $\mu \mathrm{S} / \mathrm{cm}$, microsiemens per centimeter at $25^{\circ} \mathrm{C} ; \mathrm{mg} / \mathrm{L}$, milligrams per liter; --, no data; $>$, greater than]

Well no.:Letter is cluster-site designation; WT is water table; number is depth of well below land surface.

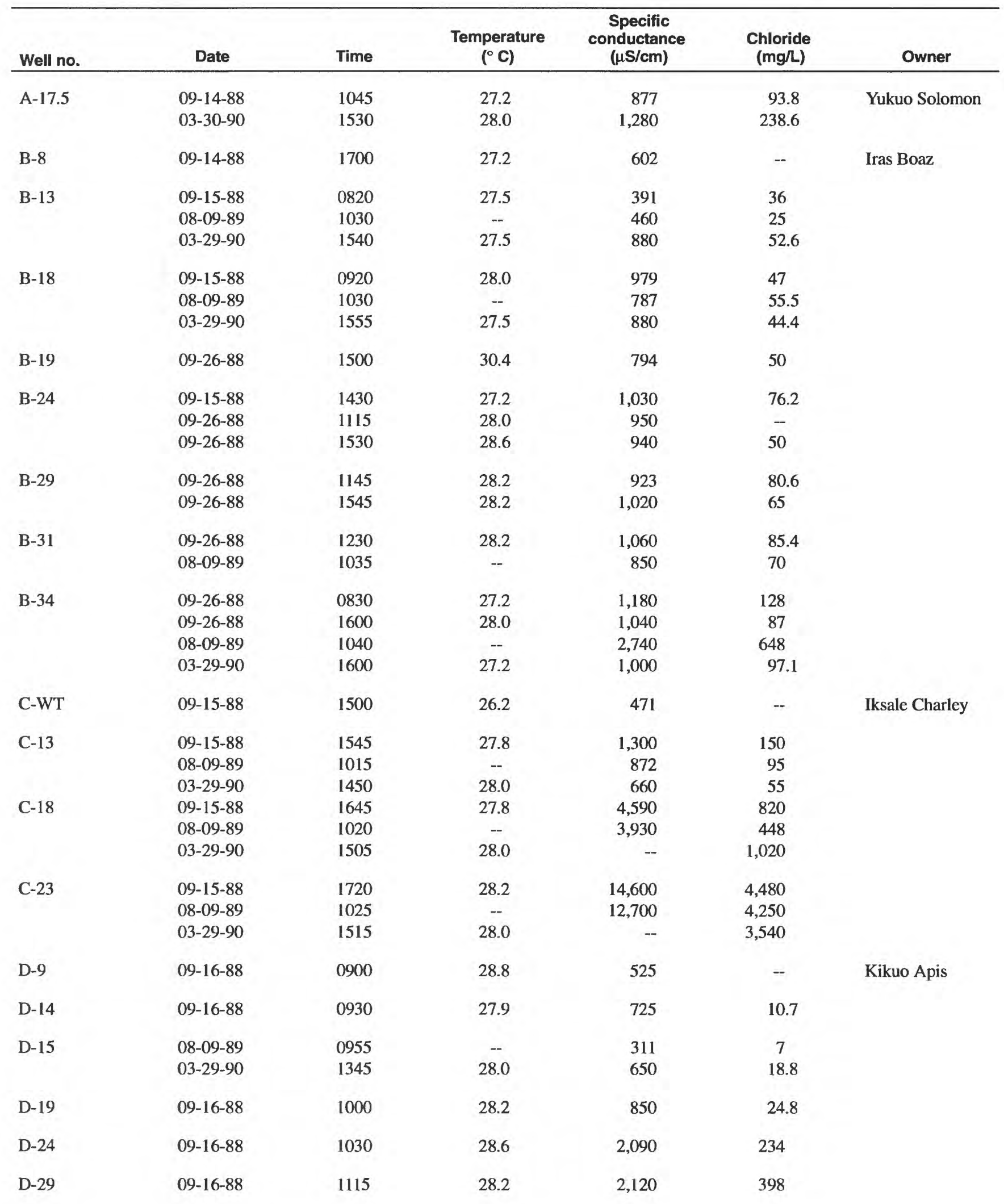


Table 3. Temperature, specific conductance, and chloride-concentration data from driven wells, Pingelap Island, Pingelap Atoll --Continued

\begin{tabular}{|c|c|c|c|c|c|c|}
\hline Well no. & Date & Time & $\begin{array}{c}\text { Temperature } \\
\left({ }^{\circ} \mathrm{C}\right)\end{array}$ & $\begin{array}{c}\text { Specific } \\
\text { conductance } \\
(\mu \mathrm{S} / \mathrm{cm})\end{array}$ & $\begin{array}{c}\text { Chloride } \\
(\mathrm{mg} / \mathrm{L})\end{array}$ & Owner \\
\hline \multirow[t]{2}{*}{ D-30 } & $08-09-89$ & 1000 & -- & 1,120 & 215 & \\
\hline & $03-29-90$ & 1400 & 27.5 & 1,900 & 386 & \\
\hline D-34 & $09-16-88$ & 1200 & 28.2 & 3,930 & 555 & \\
\hline D-39 & $09-16-88$ & 1430 & 29.2 & 5,400 & 1,540 & \\
\hline D-44 & $09-16-88$ & 1650 & 29.0 & 7,180 & 2,200 & \\
\hline D-49 & $09-17-88$ & 0830 & 27.8 & 10,750 & 3,450 & \\
\hline \multirow[t]{3}{*}{ D-54 } & $09-20-88$ & 1330 & 28.4 & 11,010 & 3,580 & \\
\hline & $08-09-89$ & 1005 & -- & 11,100 & 3,580 & \\
\hline & $03-29-90$ & 1420 & 27.5 & 10,000 & 3,180 & \\
\hline E-9 & $09-17-88$ & & 29.7 & 797 & -- & Charley Aiseam \\
\hline \multirow[t]{3}{*}{ E-14 } & $09-20-88$ & 1130 & 28.1 & 594 & 14.6 & \\
\hline & 08-09-89 & 0940 & -- & 566 & 12 & \\
\hline & $03-29-90$ & 1020 & 27.5 & 480 & 14.4 & \\
\hline E-20 & $09-20-88$ & 1135 & 28.0 & 581 & 14.2 & \\
\hline E-25 & $09-20-88$ & 1200 & 28.0 & 663 & -- & \\
\hline \multirow[t]{3}{*}{ E-30 } & $09-20-88$ & 1230 & 28.2 & 1,420 & 230 & \\
\hline & 08-09-89 & 0945 & -- & 557 & 63 & \\
\hline & $03-29-90$ & 1055 & 27.5 & 7,800 & 1,790 & \\
\hline E-35 & $09-20-88$ & 1300 & 28.4 & 13,500 & 2,850 & \\
\hline \multirow[t]{4}{*}{ E-40 } & $09-20-88$ & 1330 & 28.4 & $>20,000$ & -- & \\
\hline & $09-28-88$ & 1055 & 27.9 & $>20,000$ & 9,120 & \\
\hline & 08-09-89 & 0950 & & 20,000 & 6,820 & \\
\hline & $03-29-90$ & 1310 & 28.0 & 19,000 & 6,630 & \\
\hline F-14 & $09-20-88$ & 1600 & 28.0 & 450 & 5 & Soichy Soaz \\
\hline F-15 & $09-21-88$ & 1650 & 27.5 & 390 & 5.4 & \\
\hline F-19 & $09-20-88$ & 1620 & 27.7 & 549 & 2.6 & \\
\hline \multirow[t]{3}{*}{$\mathrm{F}-20$} & $09-21-88$ & 1700 & 27.6 & 530 & 3.5 & \\
\hline & $08-09-89$ & 0910 & - & 687 & 5.5 & \\
\hline & $03-29-90$ & 1700 & 27.5 & 780 & 2.3 & \\
\hline F-24 & $09-20-88$ & 1705 & 27.8 & 640 & 4.5 & \\
\hline F-25 & $09-21-88$ & 1730 & 27.8 & 650 & 6 & \\
\hline F-29 & $09-20-88$ & 1740 & 27.8 & 659 & 9.4 & \\
\hline F-30 & $09-22-88$ & 1415 & 27.6 & 600 & 4.6 & \\
\hline F-34 & $09-21-88$ & 1440 & 27.8 & 545 & 6. & \\
\hline F-35 & $09-22-88$ & 1650 & 28.1 & 565 & 4.4 & \\
\hline
\end{tabular}


Table 3. Temperature, specific conductance, and chloride-concentration data from driven wells, Pingelap Island, Pingelap Atoll --Continued

\begin{tabular}{|c|c|c|c|c|c|c|}
\hline Well no. & Date & Time & $\begin{array}{c}\text { Temperature } \\
\left({ }^{\circ} \mathrm{C}\right)\end{array}$ & $\begin{array}{c}\text { Specific } \\
\text { conductance } \\
(\mu \mathrm{S} / \mathrm{cm})\end{array}$ & $\begin{array}{c}\text { Chloride } \\
\text { (mg/L) }\end{array}$ & Owner \\
\hline \multirow[t]{4}{*}{ F-39 } & $09-21-88$ & 1500 & 28.0 & 560 & 6 & \\
\hline & $09-27-88$ & 0935 & 27.5 & 576 & 2.1 & \\
\hline & $08-09-89$ & 0915 & -- & 496 & 5 & \\
\hline & $03-29-90$ & 1715 & 27.5 & 530 & 3.5 & \\
\hline F-44 & $09-21-88$ & 1530 & 28.0 & 565 & -- & \\
\hline F-49 & $09-22-88$ & 1405 & 28.1 & 610 & 6.6 & \\
\hline F-54 & $09-22-88$ & 1530 & 28.5 & 615 & - & \\
\hline \multirow[t]{4}{*}{ F-57.5 } & $09-22-88$ & 1600 & 28.6 & 650 & -- & \\
\hline & $09-27-88$ & 0930 & 27.9 & 659 & 11.2 & \\
\hline & 08-09-89 & 0920 & -- & 642 & 12 & \\
\hline & $03-29-90$ & 1725 & 27.5 & 690 & 27.5 & \\
\hline G-11.5 & $09-21-88$ & & 29.2 & 860 & -- & Ampe Entere \\
\hline \multirow[t]{2}{*}{ G-13 } & $09-21-88$ & 1000 & 29.2 & 650 & -- & \\
\hline & $03-30-90$ & 1605 & 28.0 & - & 13.1 & \\
\hline \multirow[t]{2}{*}{ H-14 } & $09-21-88$ & 1300 & 29.1 & 772 & 21.6 & Bethwel Okin \\
\hline & $03-30-90$ & 1550 & 28.0 & 730 & 19.5 & \\
\hline I-9 & $09-23-88$ & 1235 & 28.9 & 759 & 20 & Iohd Hemes \\
\hline I-15 & $09-23-88$ & 1255 & 28.3 & 800 & 15 & \\
\hline \multirow[t]{2}{*}{ I-20 } & $09-23-88$ & 1315 & 28.9 & 800 & 20 & \\
\hline & $08-09-89$ & 1105 & -- & 733 & 15 & \\
\hline I-25 & $09-23-88$ & 1340 & 28.0 & 825 & 25 & \\
\hline I-30 & $09-23-88$ & 1525 & 28.1 & 890 & 38.1 & \\
\hline I-35 & $09-23-88$ & 1600 & 29.2 & 929 & 40.5 & \\
\hline \multirow[t]{3}{*}{ I-40 } & $09-23-88$ & 1640 & 29.0 & 1,080 & 54.3 & \\
\hline & $08-09-89$ & 1110 & -- & 825 & 35 & \\
\hline & $03-29-90$ & 1625 & 27.5 & 7,000 & 51.9 & \\
\hline I-45 & $09-23-88$ & 1730 & 29.1 & 1,525 & 85 & \\
\hline I-50 & $09-24-88$ & 0825 & 28.4 & 3,130 & 245 & \\
\hline I-53 & $09-24-88$ & 0915 & 29.8 & 4,750 & -- & \\
\hline \multirow[t]{4}{*}{ I-53.5 } & $09-24-88$ & 0950 & 29.8 & 6,300 & -- & \\
\hline & $09-27-88$ & 0910 & 27.5 & 7,180 & 2,020 & \\
\hline & $08-09-89$ & 1115 & -- & 7,050 & 2,040 & \\
\hline & $03-29-90$ & 1645 & 27.5 & 8,000 & 1,760 & \\
\hline $\mathrm{J}-8$ & \multicolumn{2}{|c|}{ Not enough water to pump } & & & & Aran Daniel \\
\hline J-9 & \multicolumn{2}{|c|}{ Not enough water to pump } & & & & \\
\hline
\end{tabular}


Table 4. Water-quality data from selected dug and driven wells collected March 1990, Pingelap Island, Pingelap Atoll [Temp, temperature; $\mathrm{ALK}$, total alkalinity; $\mathrm{Ca}$, calcium; $\mathrm{Mg}$, magnesium; $\mathrm{Sr}$, strontium; $\mathrm{Na}$, sodium; $\mathrm{K}$, potassium; $\mathrm{Cl}$, chloride; $\mathrm{SO}_{4}$, sulfate; $\mathrm{NO}_{3}$, nitrate; $\mathrm{PO}_{4}$, phosphate; ${ }^{\circ} \mathrm{C}$, degrees Celsius; meq/L, milliequivalents per liter; $\mathrm{mg} / \mathrm{L}$, milligrams per liter; --, no data; <, less than]

Well no.: DW, dug well and number is well designation; letters $\mathrm{A}$ through $\mathrm{N}$ are driven-well cluster-site designations, and number is depth of well below land surface.

\begin{tabular}{|c|c|c|c|c|c|c|c|c|c|c|c|c|}
\hline Well no. & $\begin{array}{l}\text { Temp } \\
\left({ }^{\circ} \mathrm{C}\right)\end{array}$ & pH & $\begin{array}{c}\text { ALK } \\
\text { (meq/L) }\end{array}$ & $\underset{(\mathrm{mg} / \mathrm{L})}{\mathrm{Ca}}$ & $\underset{(m g / L)}{M g}$ & $\underset{(\mathrm{mg} / \mathrm{L})}{\mathrm{Sr}}$ & $\begin{array}{c}\mathrm{Na} \\
(\mathrm{mg} / \mathrm{L})\end{array}$ & $\underset{(\mathbf{m g} / L)}{\mathrm{K}}$ & $\underset{(\mathrm{mg} / \mathrm{L})}{\mathrm{Cl}}$ & $\underset{(\mathrm{mg} / \mathrm{L})}{\mathrm{SO}_{4}}$ & $\begin{array}{c}\mathrm{NO}_{3} \\
(\mathrm{mg} / \mathrm{L})\end{array}$ & $\begin{array}{c}\mathrm{PO}_{4} \\
(\mathrm{mg} / \mathrm{L})\end{array}$ \\
\hline DW-1 & 28.5 & 7.24 & 7.57 & 220 & 138 & 3.5 & 1,170 & 39.9 & 2,230 & 290 & 0.066 & 0.274 \\
\hline DW-2 & 28.5 & 7.12 & 8.43 & 129 & 32.6 & 2.0 & 95.5 & 2.9 & 152 & 19.0 & 530 & 0.585 \\
\hline DW-4 & 27.0 & 7.14 & 8.05 & 148 & 7.0 & 2.7 & 32.8 & 0.2 & 36.5 & 15.0 & 0.045 & 0.111 \\
\hline DW-5 & 28.0 & 7.16 & 6.22 & 111 & 7.8 & 1.1 & 7.1 & 1.1 & 8.4 & 2.0 & 0.027 & 0.881 \\
\hline DW-6 & 27.5 & 7.18 & 8.60 & 157 & 9.5 & 2.3 & 30.2 & 3.7 & 37.7 & 5.7 & 0.024 & 0.400 \\
\hline DW-7 & 28.0 & 7.05 & 10.1 & 173 & 15.6 & 2.2 & 73.3 & 8.8 & 83.4 & 28.0 & 0.054 & 0.179 \\
\hline DW-8 & 28.0 & 7.76 & 6.08 & 108 & 8.4 & 1.6 & 16.1 & 2.1 & 18.6 & 1.0 & 0.032 & 0.507 \\
\hline DW-9 & 27.5 & 7.42 & 6.59 & 103 & 12.4 & 1.0 & 5.2 & 0.6 & 4.8 & 1.8 & 0.498 & 0.113 \\
\hline DW-10 & 27.5 & 7.52 & 7.09 & 113 & 13.1 & 1.1 & 22.4 & 0.5 & 16.8 & 9.2 & 1.63 & 0.074 \\
\hline DW-11 & 27.0 & 7.23 & 8.90 & 144 & 15.4 & 1.3 & 21.6 & 2.1 & 29.4 & 6.8 & 0.084 & 0.255 \\
\hline DW-13 & 29.5 & 7.30 & 7.53 & 131 & 10.4 & 1.6 & 9.7 & 3.1 & 7.7 & 1.4 & 0.043 & 0.323 \\
\hline DW-14 & 27.0 & 7.38 & 7.61 & 106 & 24.3 & 1.2 & 10.8 & 0.5 & -- & 2.5 & 0.251 & 0.009 \\
\hline DW-15 & 27.0 & 7.37 & 6.96 & 98.0 & 24.3 & 1.1 & 19.0 & 3.8 & 34.4 & 2.7 & 0.005 & 0.003 \\
\hline DW-16 & 26.5 & 7.44 & 6.87 & 107 & 15.5 & 1.1 & 5.7 & 0.5 & 5.7 & 3.8 & 0.164 & 0.179 \\
\hline DW-17 & 27.5 & 7.27 & 8.15 & 145 & 14.5 & 2.1 & 16.8 & 1.5 & 20.8 & 25.0 & 0.149 & 0.144 \\
\hline DW-18 & 27.5 & 7.37 & 6.71 & 197 & 77.4 & 3.3 & 733 & 30.7 & 1,330 & 130 & 0.012 & 0.445 \\
\hline DW-19 & 28.0 & 7.24 & 8.07 & 158 & 18.3 & 1.8 & 90.4 & 11.9 & 85.0 & 120 & 1.00 & 2.16 \\
\hline DW-20 & 27.5 & 7.25 & 7.78 & 163 & 8.1 & 2.5 & 20.2 & 1.1 & 27.0 & 32.0 & 0.056 & 0.783 \\
\hline DW-21 & 27.0 & 7.24 & 8.26 & 136 & 14.3 & 1.4 & 40.8 & 3.9 & 39.6 & 16.0 & 0.769 & 0.174 \\
\hline A-18 & 28.0 & 7.17 & 6.80 & 123 & 24.5 & 1.3 & 131 & 4.1 & 239 & 19.0 & 0.009 & 0.019 \\
\hline B-13 & 27.5 & 7.60 & 8.17 & 95.1 & 41.2 & 2.7 & 34.3 & 0.6 & 52.6 & 4.5 & 0.009 & 0.023 \\
\hline B-18 & 27.5 & 7.85 & 8.56 & 97.9 & 46.2 & 3.4 & 33.0 & 0.6 & 44.4 & 5.3 & 0.011 & 0.046 \\
\hline B-34 & 27.2 & 7.44 & 7.91 & 90.7 & 43.7 & 3.1 & 62.8 & 1.5 & 97.1 & 15.0 & 0.008 & 0.013 \\
\hline C-13 & 28.0 & 7.20 & 7.75 & 144 & 11.6 & 2.0 & 36.5 & 1.1 & 55.0 & 4.7 & 0.019 & $<0.001$ \\
\hline C-18 & 28.0 & 8.24 & 6.46 & 41.3 & 100 & 1.8 & 605 & 22.8 & 1,020 & 82.0 & 0.011 & 0.002 \\
\hline C-23 & 28.0 & 7.54 & 6.11 & 96.0 & 256 & 2.5 & 1,990 & 72.5 & 3,540 & 410 & 0.005 & 0.005 \\
\hline D-15 & 28.0 & 7.28 & 6.48 & 115 & 6.9 & 1.6 & 13.8 & 0.5 & 18.8 & 1.2 & 0.003 & 0.406 \\
\hline D-30 & 27.5 & 7.94 & 5.93 & 61.7 & 39.2 & 1.4 & 268 & 10.3 & 385 & 22.0 & 0.020 & 0.057 \\
\hline D-54 & 27.5 & 8.86 & 1.90 & 26.7 & 175 & 0.8 & 1,800 & 65.2 & 3,180 & 280 & 0.032 & $0.013^{\circ}$ \\
\hline E-14 & 27.5 & 7.27 & 5.64 & 102 & 5.2 & 1.6 & 10.1 & 0.5 & 14.4 & 0.3 & 0.008 & 0.642 \\
\hline E-30 & 27.5 & 7.18 & 7.21 & 181 & 106 & 3.0 & 981 & 35.3 & $1,788.0$ & 200 & 0.006 & 0.275 \\
\hline E-40 & 28.0 & 8.07 & 4.85 & 141 & 452 & 3.0 & 3,690 & 137 & 6,640 & 940 & 0.016 & 0.031 \\
\hline F-20 & 27.5 & 7.13 & 8.60 & 150 & 9.2 & 1.5 & 3.4 & 0.1 & 2.3 & 1.6 & $<0.001$ & 0.006 \\
\hline F-39 & 27.5 & 7.43 & 5.64 & 94.8 & 8.2 & 1.2 & 3.3 & 0.3 & 3.4 & 0.5 & 0.005 & $<0.001$ \\
\hline F-57.5 & 27.5 & 7.59 & 6.86 & 50.9 & 49.6 & 2.9 & 19.7 & 1.1 & 27.5 & 1.1 & 0.020 & 0.003 \\
\hline G-13 & 28.0 & 9.50 & 1.50 & 7.1 & 8.2 & 0.1 & 19.1 & 0.6 & 13.1 & 0.4 & 0.009 & 0.006 \\
\hline H-14 & 28.0 & 7.12 & 5.76 & 135 & 16.5 & 1.1 & 12.7 & 0.5 & 19.5 & 6.1 & 1.19 & 0.019 \\
\hline I-40 & 27.5 & 8.75 & 5.72 & 9.5 & 160 & 0.3 & 977 & 38.3 & 1,760 & 190 & 0.009 & 0.011 \\
\hline I-53.5 & 27.5 & 8.37 & 6.46 & 24.7 & 46.5 & 1.3 & 59.4 & 6.5 & 51.9 & 0.4 & 0.003 & 0.028 \\
\hline
\end{tabular}

